Quarterly Journal of the Geological Society

\title{
On some Secondary Fossils from South Africa
}

Ralph Tate

Quarterly Journal of the Geological Society 1867, v.23; p139-175.

doi: 10.1144/GSL.JGS.1867.023.01-02.24

Email alerting

service

Permission

request

Subscribe click here to receive free

e-mail alerts when new articles

cite this article

click here to seek permission

to re-use all or part of this

article

click here to subscribe to

Quarterly Journal of the

Geological Society or the Lyell

Collection

\section{Notes}

(C) The Geological Society of

London 2012

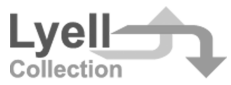


THE

\section{QUARTERLY JOURNAL}

\section{OF \\ THE GEOLOGICAL SOCIETY OF IONDON.}

\section{PROCEEDINGS}

OF

\section{THE GEOLOGICAL SOCIETY.}

\section{February 6, 1867.}

R. G. M. Browne, Esq.: Admiralty Registrar, Doctors' Commons, and 9 College Crescent, Hampstead, N.W.; the Rev. Michael Alfred Moon, Cleator, near Whitehaven ; and Benjamin B. Orridge, Esq., 33 St. John's Wood Park, N.W., were elected Fellows.

The following communications were read :-

1. On some Secondary Fosstus from Sotth Africa. By Ralph Tate, Esq., A.L.S., F.G.S.

$$
\text { [Puates V.-IX.] }
$$

I. Introduction.

Contentón.

II. Karoo Beds.

a. Fossil Flora of the Karoo Beds.

$b$. General Remarks on the Fossil Plants of the Karoo Beds.

c. Synopsis of the Karoo Beds, by Professor T. Rupert Jones, F.C.S.

III. Uitenhage Series.

a. Fossil Flora of the Geelhoutboom Series.

b. General Remarks on the same.

c. Synopsis of the Uitenhage Series, by Prof. T. Rupert Jones, F.G.S.

d. Description of some Jurassic Fossils from Uitenhage, South Africa.

$e$. General Remarks on the Jurassic Fauna of South Africa.

IV. Observations on the Secondary Strata of South Africa, and on their foreign equivalents.

$\nabla$. Table of the Organic Remains of the Uitenhage Formation.

a. Flora of the Wood-bed Series at Geelhoutboom.

$b$. Fauna of the Uitenhage Formation.

\section{INTRODUCTION.}

As a large number of fossils from the Secondary rocks of South Africa remain undescribed in the Society's Museum, it seems desirable that an account of them should be submitted to the Society, as 
a sequel to the Monographs on Secondary Fossils from South Africa which have appeared in the Society's Transactions and Quarterly Journal.

This paper contains descriptions of the Plants of the Karoo beds, the Reptilian and Molluscan life of which has been made known by the labours of Professors Owen and Huxley, and the late Mr. Daniel Sharpe-of the vegetable remains from the phytiferous beds of Geelhoutboom, and of the fossils from the Jurassic strata of the Zwartkop and Sunday's River (the last part being a Supplement to Mr. Daniel Sharpe's "Descriptions of Fossils from the Secondary Rocks of South Africa"). The study of the organic remains of the beds enumerated has enabled me to offer, in addition, some generalizations on the affinities of each of the above-mentioned groups of Secondary strata developed in this region.

\section{KAR0o BEDS.}

\section{a. Fossil Flora of the Karoo Beds.}

1. Glossopterts Browntana, Pl. VI. figs. $5 a, 5 b, 7 a, 7 b$.

The Society is in possession of several impressions of a Glossopteris, in a friable sandstone, obtained by Dr. W. G. Atherstone, F.G.S., from Heald Town, near Fort Beaufort, Eastern Province, South Africa,-and many others of the same form, in a dark shale, from Bloemkop *, collected by Mr. C. J. Powell, of Graaf Reinet, and presented by Dr. R. N. Rubidge, F.G.S. There are also in the Collection some well-preserved specimens from Natal, that were collected and sent to England by Dr. P. C. Sutherland. These all agree, in the main, with Glossopteris Browniana.

The following words employed by Sir C. Bunburyt, on comparing the Indian Glossopteris with the common Australian G. Browniana, are applicable when the Glossopteris from Natal is compared with the G.Browniana:- "I can find no satisfactory specific distinction; the venation is essentially the same. We may, indeed, find African specimens in which the meshes of the reticulation near the midrib are larger and broader than in the ordinary Australian plant, and others in which the veins are more strongly recurved; but in both the Indian and Australian plants I find so many shades of variation in these particulars that I cannot attach much importance to them."

The apex of the African plant is obtuse, like that of the Australian plant, and never acute as in the Indian. The frond is more attenuated below in the African fern; but there seems to be some degree of variation in this particular. It has a more firm and rigid appearance than the Indian and Australian forms.

2. Glossopteris Suthertandr, spec. nov. Pl. VI. figs. $2 a, 2 b$.

This species, dedicated to Dr. P. C. Sutherland, Surveyor-General of Natal, its discoverer, is associated with G.Browniana in the coal-

* Quart. Journ. Geol. Soc. vol. xv. p. 198; and vol. xvii. p. 329.

† Ibid. vol. xvii. p. 328. 
deposits of Natal; the materials at my command consist of fragments of fronds, the distinctive eharacters of which may be thus stated:-Frond narrow, strap-shaped, with nearly parallel edges; apex obtuse (?). Midrib narrow, continued to the apex. Lateral veins strong, slightly oblique, dichotomous, anastomosing and forming a lax network from the midrib to the margin.

Locality. Natal (Dr. P. C. Sutherland).

3. With the above-mentioned specimens from Bloemkop are some of an apparently, at first sight, second species of Glossopteris ; these do not exhibit fructification. Dr. Rubidge, however, has communicated a drawing (by Mr. M Kay) of a specimen of this species obtained by Mr. M'Kay near East London: and I find that it presents characters generically distinct from those of Glossopteris; for the position of the fructification is indicated by a few large elevated. rings, arising from many veins, and somewhat regularly arranged in a row coincident with the margin, and not by numerous spots, small in size, supported by one vein, distributed over mueh of the surface of the frond. This new genus thus bears the same relation to Glossopteris, among fossil ferns, that Acrostichum does to Polypodium among living forms.

I propose for this genus the name Rubidgea, in compliment to Dr. R. N. Rubidge, F.G.S. One species only is known, the characters of which are as follows:-

Rubidgat Mackayi, gen. et spec. nov. P1. V. fig. 8.

Frond oblong, obovate, rounded and obtuse at the apex ; secondary veins very slender, very much crowded, dichotomous, oblique. There is no indication of anastomosis of the veins.

Localities. Bloemkop, near the Sunday's River, Graaf Reinet (Dr. Rubidge); East London, at the mouth of the Buffalo River (Mr. M(Kay).

4. Dictyopterts? smiplex, spec. nov. Pl. VI. fig. 6.

The material at my command consists of a fragmentary specimen of a single frond, showing neither base nor apex.

Frond simple, large, oblong, broad (?); venation arising from a prominent midrib, and forming a lax and regular network, composed of elongated subquadrangular areolæ.

This species, in the form of its frond, approaches Glossopteris: but its venation is more like that of Dictyopteris than of Glossopteris. The specimen is on a brownish-grey shale from Bloemkop (Graaf Reinet), and was presented by Dr. Rubidge; it was alluded to by Sir C. Bunbury in 1861 as " consisting of mere fragments, with veins forming a lax and regular network, perhaps more like the venation of Dictyopteris than of Glossopteris." (Quart. Journ. Geol. Soc. vol, xvii. p. 329.)

5. Specimens of flattened stems are not rare in the shales of Bloemkop ; they appear to belong to Phyllotheca (Pl. V. fig. 6) ; but as the materials are very imperfect, I refrain from attaching any 
specific title. The shales with Phyllotheca are dark-grey, somewhat calcareous, and associated with a band of obscure Bivalves (Iridince?).

b. General Remarks on the Fossil Plants of the Karoo Beds.

1. A marked feature in the ancient flora of the Karoo district is the paucity of specific forms (five in number), in proportion to the abundance of specimens (forty in the Collection).

2. This flora presents close analogy with that of the Coal-formation of Eastern Australia and the plant-bearing beds of Burdwan and Nagpur in India. The characteristic plant in each of these deposits and in the Karoo beds is a Glossopteris; and it seems that the Indian, Australian, and South-African plants are specifically identical.

The association of the genera Glossopteris, Phyllotheca, and Dic- tyopteris(?) affords some evidence of Mesozoic affinities in this fossil flora.

3. From the very characteristic Jurassic flora presented by the Geelhoutboom shales and limestones (which, from the structure of the country, may be confidently regarded as being higher in the geological scale), the flora of the Karoo beds (which has no affinity with the former) cannot be regarded as contemporaneous with the Jurassic flora of Europe; but, as it possesses a Mesozoic facies, it may be considered to be of Triassic age.

4. The nature of the flora conspires with the fauna to establish the lacustrine origin of the Karoo series. The following synopsis (by Prof. RUPERT JONEs) of these beds and their vertebrate and other fossils (as far as hitherto described) embraces the characteristics of this remarkable formation.

\section{c. Synopsis of the Karoo Beds.}

The Karoo Beds*, as far as described by the late Mr. Bain, appear to comprise (beginning with the lowest) :-

1. The Ecca Beds. Hard blue shales (with Plant-remains resembling those of the still higher Beaufort Beds) alternating with variegated and rippled sandstones, and containing some thin layers of hard, blue, impure, nodular limestone. They are divisible into an Upper and a Lower series $\uparrow$, separated by, and lying conformable with, the remarkable band of igneous rock $\ddagger$ which extends across South Africa. In the lower portion of the Ecca Beds Mr. Bain noticed a band of vegetable remains 9 inches thick (at Ecca Heights). The fossil wood on the Pattates River, in the Great Karoo, belongs to the Ecca Zone.

2. The Koonap Beds. Sandstones and hard shales, with fossil trees at the Kleine Roggeveld.

* Mr. Bain referred to these as the "Karoo Formations" in the East. Prov. Magaz. 1856, p. 19.

$\dagger$ Dr. Rubidge seems to regard this lower band, underlying the great trapbreccia, as being probably a part of the. Devonian series of strata.

$\ddagger$ On the flanks of the Zuurberg it is decidedly a dolerite, containing angular and rounded fragments of quartzite and granite. This trap-breceia and the Ecca beds have participated in the foldings by which the quartzites and schists (Devonian) of the Zuurberg have been raised into a ridge. 
3. The Beaufort Becls (Beaufort West and Fort Beaufort are both on this band). Greenish laminated sandstone, with shale, calcareous banids*, and numerous hard nodular masses often containing Dicynodont remains $\uparrow$. Fossil wood is common ; and Dr. Gray found fossil Ferns near Cradock. The "Fort-Beaufort Grit," containing Glossopteris, Palconiscus (?), Oudenodon Bainii, Owen, and Oud. prognathus, $O$ wen, is a band of coarse sandstone towards the base of this zone. Small bivalves also have been found in zone No. 3, at Manzalan (on the Kat River), and near Graaf Reinet $\ddagger$; and Glos-

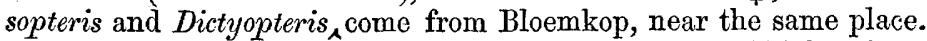
A peculiar Fern (Rubidgea Mackayi, see above, p. 141) has been found in this zone by Mr. Mr'Kay near the sea-level at East London (Buffalo River Mouth). Dicynodont remains are numerous in "No. 3," near Fort Beaufort and the Mankazan Post; and from Blinkwater, in the same distriet, Mr. Bain got the remains of a large Reptile with 60 fluted and serrated teeth (his "Blinkwater Monster" §). His "Gamkasaurus" (an immense reptile, as yet undescribed) also belongs to this zone in Beaufort West; also his "Asterophyllites?" and "Lycopodium?" of the Roggeveld\|. Dicynodon lacerticeps, O., D. strigiceps, O., D. Bainii, O., and D. tigriceps, 0 ., came from the same set of beds, at various localities, east and west; and from the higher and more northern portion of the zone have been obtained:-Palceoniscus (Spitzkop and Styl Krantz) and other Fish-remains (Brak River); a Reptile having the characters of the "Blinkwater Monster" ", but smaller (Sneeubergen); Micropholis Stowii, Huxley, Dicynodon declivis, O., D. latirostris, O., D. verticalis, O., Oudenodon Grayii, O., Galesaurus planiceps, 0. , Cynochampsa laniarius, O., and a portion of an Encrinital Stem*** from the Rhenosterberg; and Dicynodon Murrayii, Huxley, still further north, near Colesberg. The buff-coloured, soft, stratified sandstone of the Great Winterberg is described as equivalent to the Sneeuberg beds, as well as the Tarka beds with pisolitic iron-ore (?) and Dicynodons. Possibly, however, the higher portions of the series in the Sneeuberg and Winterberg Heights may be outliers, belonging to the next or Stormberg beds; if so, the Palcooniscus of Styl Krantz, and the Reptile with serrated teeth from the Sneeuberg, belong to the next series.

4. The Stormberg Beds (Huxley th), or the white and yellowish sandstones, with grey and reddish shales, of the Stormberg and of

* See Mr. Stow on the Rhenosterberg, Quart. Journ. Geol. Soc. vol: xv. p. 194.

+ Some at least of these nodular masses are penetrated by greenstone, numerous dykes and beds of which abound throughout the "Karoo Series."

$\$$ Iridince, \&c., Transact. Geol. Soc. 2nd ser. vol. vii. p. 225.

\& Eastern Prov. Monthly Mag. vol. i.pp. 9-11; Newspaper Letter (June 1861); and Geol. Trans. 2nd ser. vol. vii. p. 56 .

|| Trans. Geol. Soc. 2nd ser. vol, vii. p. 188 \& p. 227.

T. Letter in Newspaper (Fort-Beaufort Advocate, June 1861).

** If not a derived fossil, washed in from the Deronian beds, this is inimical to the supposed lacustrine origin of the Karoo beds.

t† Quart. Journ. Geol. Soc. vol. xxiii. p. 5. [I have lately found that Mr. Wyley has also used the same name. July.-T. R. J.] 
Bloemfontein* succeed. These have:--silicified wood and coal or lignite; Dicynodon (D. testudiceps, Owen, from the River Modder); Euskelesaurus Brownii, Hux., and Orosaurus, Hux., from Aliwal North ; and Cynochampsa laniarius (?), O., Massospondylus, O., Pachyspondylus, 0 ., and Leptospondylus, 0 ., from Harrismith, near the Drakenberg.

Zone No. 4 comes out on the Natal side of the Drakenberg, and possibly the lower zones also. Glossopteris, in a good state of preservation, together with fossil wood and bones, in a calcareous rock, have been collected by Dr. P. C. Sutherland $\uparrow$ from the upper strata of the Coal-series of Natal.-T. R.J.

\section{Uitenhage Series.}

a. Fossil Flora of the Geelhoutboom Beds (the "Wood-bed Series" of Atherstone).

The plants from the Geelhoutboom series have been obtained by Dr. Atherstone and Dr. Rubidge at various datos; they have been derived from two kinds of deposit (forming part of the "Woodbed"):-

1. A soft grey sandy shale, and yellowish sandstone (the remains of the leares are sometimes calcareous).

2. A dull, compact, splintery, bluish-grey, argillaceous limestone, lying below the marly sandstone. Of this rock there are two layers ("strata of ferns" in Dr. Atherstone's section $\ddagger$ ).

No. 1. contains Palcozamia Morrisii, P. Rubidgei, Athrotaxites (sp.), Cycad stems, Sphenopteris Antipodum, Pecopteris Africana, and $P$. Rubidgei.

No. 2. contains Palcoozamia recta, P. Africana, seeds and a portion of a cone belonging to Cycadaceous plants, and Pecopteris Atherstonei.

The following species are common:-Asplenites lobata and $C y$ clopteris Jenkinsiana.

Description of the Species.

\section{A. Cycadacece.}

1. Patemozamia (Otozamttes) pecta, spec. nov. Pl. V. figs. $7 a, 7 b$.

Frond pinnate, elongated. Pinnæ alternate, lanceolate, tapering gradually to an acute apex, patent; base semicordate; veins distinct, forked, nearly parallel.

The foliage of this species, so far as it.is known, was exceedingly coriaceous; many of the pinnæ are mined with serpentinous galleries, as by the larvæ of Insects. A frond of P. recta in the Geological Society's Museum measures 17 inches in length; its apex is wanting; but when entire, it must have exceeded 2 feet 6 inches.

* These are described by Mr. A. Wyley in a Report (addressed to the President of the Free State) on the ineffectual search for gold near this place: 'Bloemfontein Gazette,' January 1856.

+ Quart. Journ. Geol. Soc. vol. xi.p. 466 .

$\ddagger$ Provincial Magazine, vol. i. pp. 580, 581 (1857). 
$P$. recta differs from $P$. gigas, Lindley and Hutton, in its linear lanceolate pinnæ, and approaches nearer to $P$. lanceolata, Leckenby, from which it is distinguished by its straight pinnæ, and by their proportionate length and breadth. The length of a pinna of $P$. recta is about six times the breadth.

2. Paraozamia (Podozamrters) Morrisir, spec. not. Pl. V. fig. 4.

Frond bipinnate (?); pinnæ somewhat approximate, patent, ovatelanceolate; apex acute; base contracted. Length from $2 \frac{1}{2}$ to $3 \frac{1}{2}$ times the breadth; venation obscured.

This well-marked species is dedicated to Professor John Morris, F.G.S., who many years since paid attention to the fossil flora of South Africa.

3. Parteozamia Rubidget, spec. nov. Pl. V. figs. $3 a, 3 b$.

Frond pinnate, rachis straight, broad; pinnæ alternate, long, slender, lanceolate, tapering gradually to an acute apex; base slightly contracted, and decurrent (?) ; veins about ten, prominent, parallel.

The substance of the pinnæ was apparently thin; the plant being either succulent, or possessing a much less coriaceous cuticle than is found usually among Cycads allied to Zamia.

Palceozamia Rubidgei is related to Zamites lanceolatus, Lindley and Hutton; but the pinnæ are not so distant, and are more lanceolate.

4. Paterozamia (vel Pterophyllum) Africana, spec. nov. Pl. V. fig. 5.

Frond - ? Pinnæ very long, lanceolate, tapering gradually; apex — ? ; base —— ? ; veins few (about six), prominent, parallel.

This species is founded on a portion of a frond, the full length of which is not seen, nor the insertion and termination of the pinnæ. The longest pinna, in its incompleteness, measures $5 \frac{3}{4}$ inches.

The long, slender, and nearly parallel-sided pinna is not referable to any other African Cycad, nor, as far as I know, to any Palcoozamia ; it may, however, prove to belong to the genus Pterophyllum; in which case P. Africana finds an analogue in Pt. Morrisianum, Oldham, from the Coal-measures of Rajmahal, India ; but it differs from the latter by its more slender form, and its fewer and coarser veins. The same characters would distinguish it from Podozamites longifolius, Emmons.

\section{B. Filices.}

1. Pecopteris Athenstonei, spec. nov. Pl. V. figs. $2 a, 2 b$.

Frond possibly bi- or tripinnate; pinnæ long, pinnatifid, with close, alternate, decurrent segments, which are oblong and slightly oblique; medial vein nearly straight, prominent; secondary veins oblique, forked once near the midrib.

This species is closely allied to $P$. . Indica, Oldham and Morris, but is of a more robust habit; the pinnules are broader and blunter. 
2. Pecopteris Rubidget, spec. nov. Pl. V. figs. $1 a, 1 b$.

- Pinnæ long, pinnules attached to the rachis by their whole base and to each other, close, alternate, falcate, acute; median vein strong, prominent; secondary veins oblique, forked once near the midrib.

The arched and acutely pointed pinnules serve to distinguish this species from P. Atherstonei.

3. Pecorteris Africana, spec. nov. Pl. VI. figs. $1 a, 1 b$.

Pinnæ long; pinnules attached by a contracted base, distant, patent, elongate-oblong, blunt or subacute; medial vein strong; secondary veins oblique and bifurcating, or simply forked.

4. Asplenites lobata, Oldham, ' Palæontologia Indica,' p. 52, pl. 28. fig. 1, pl. 29, pl. 30, pl. 36. figs. 6, 7: 1860 .

This fern is the most abundant of the plants of the Geelhoutboom marls; it also occurs in a dark-grey subcrystalline limestone at Geelhoutboom.

Of $A$. lobata, described from the coal-series of Rajmahal, India, the diagnosis is as follows:-

"Frond bipinnate; pinnæ oblique, long, alternate ; pinnules ovate, alternate, distant, contracted at the base, lobed ; lobes obtuse, deep, 4 to 8 on each side; midrib stiff and proceeding to the end of the pinnule, secondary veins flexuous and divided once or twice (?); sori oblong or oblong-triangular, very large."-Oldham.

The African specimens do not exhibit any traces of fructification.

5. Sphenopteris ANTIPODUM, spec. nov. Pl. VI. fig. 3.

Frond bipinnate, with linear, long, acute, dentated, alternate segments, each of which has one vein : the primary pinnæ on slender stalks, elongated, oval.

This species has great analogy to S. Fulgeri, Ettingshausen, from the Wealden at Deister, and from the Inferior Oolite in Yorkshire; but its pinnules are not so membranous and laciniated as in that species.

6. Cyclopteris Jenkinsiana, spec. nov. Pl. VI. fig. 4.

Frond obovate-oblong, rounded and obtuse at the apex, somewhat attenuated below; the veins, which are numerous and delicate, are radiate, dichotomizing from the base.

The length of the largest specimen is $4 \frac{3}{8}$ inches, and the greatest breadth $3 \frac{2}{8}$ inches.

"In the overlying sandstone they are often 5 or 6 inches long and 3 inches broad" (Dr. W. G. Atherstone, MS.). The base is not preserved, but was apparently simply attenuated.

This species occurs both in the argillaceous limestones and in the laminated sandstones of Geelhoutboom.

I have much pleasure in dedicating this species to my colleague, Mr. H. M. Jenkins, F.G.S., as a slight acknowledgment of the services he has rendered me in the issue of this paper. 
7. In addition to the above-enumerated species there are associated with them portions of a Coniferous stem closely allied to Athrotaxites Indicus, Oldham, of the Rajmahal coal-series; parts of stems, presenting longitudinal tuberculated ridges, probably Cycadaceous ; and ovules of Palceozamia, and the under surface of the base of a cone, perhaps of the same.

\section{b. General Remarks on the Fossil Plants from Geelhoutboom.}

The plant-bearing beds of Geelhoutboom are (according to the observations of Bain and others) younger than the "Karoo Series," or "Dicynodon strata," the flora of which is described above (p. 140); but they are inferior in position to those strata on the Sunday's River (the "Trigonia-beds") that yield marine fossils of undoubted Jurassic age. Accepting the conclusions arrived at respecting the age of the beds newer and older than the plant-bearing strata of Geelhoutboom, any evidence that an examination of these plants may afford as to the Jurassic aspect of this flora will be very valuable as a confirmation of its age, already inferred from the stratigraphical position of the beds themselves. That the flora does bear evidence of such a Jurassic relationship, I will proceed to point out.

The specimens collected by Dr. Rubidge in 1845, at the Sunday's River (Geelhoutboom), were examined by Prof. Morris*, who gave as his opinion that they " are essentially 'Secondary' in character, from the preponderance of the remains of Cycadece, and probably represent a Triassic or a Jurassic flora." The same plants were exhibited at the Ipswich Meeting of the British Association (1851), on which occasion Dr. Harvey stated that " the species of Pecopteris, Neuropteris, and Sphenopteris chiefly resemble those of the coal of Australia, whilst the presence of Zamia in abundance impresses an Oolitic aspect on the flora" $\uparrow$.

Though the collection of these plants has been greatly increased by the further liberality of Dr. Atherstone and Dr. Rubidge, yet the views advanced by Prof. Morris are still applicable ; but Dr. Harvey's statement must be accepted with some limitation.

The collection, though rich in individuals, is poor in species, and has yielded the following:-

\begin{tabular}{|c|c|c|}
\hline \multicolumn{3}{|c|}{4 species of Paloeozamia. } \\
\hline & פ & Athrotaxites. \\
\hline & & Cyclopteris. \\
\hline & & enopteri \\
\hline & & Asplenites. \\
\hline 6 & , & Pecopteris. \\
\hline
\end{tabular}

* British Assoc. Rep. 1851, Trans. Sect. p. 68.

+ [Trans. Geol. Soc. 2nd ser. vol. vii. p. 227, note. There was for some time considerable doubt respecting the real localities of the Fossil Plants referred to in the foot-notes at p. $185 \&$ p. 227 , vol. vii. Trans. Geol. Soc. 2nd ser. The same specimens are alluded to in these two notes. Most of them came from Geelhoutboom; but some were from the Karoo Beds at Jackal's Kop, on the eastern side of the Stormberg (Quart. Journ. Geol. Sec. vol. xii. p. 237); and these latter do not appear among those that ultimately came into the possession of the Society, and which Professor Morris examined.-T. R.J.] 
The four species of Cycadaceous plants which constitute the bulk of the flora are founded on fronds. One of these belongs to the section Otozamites of the genus Palceozamia, species of which characterize Jurassic rocks, and are chiefly found in the Lias and Lower Oolites. They greatly resemble, though quite distinct, several species from the plant-bearing beds of the Yorkshire coast.

The presence of Cycads in the "Uitenhage Series" of South Africa is of interest when we regard the distribution of these vegetables in time. Hitherto plants with Cycadeous affinities, and belonging to the Jurassic epoch, have been met with only in the northern hemisphere. Their discovery in South Africa in beds of the same age that have yielded them in Europe, India, and North America demonstrates the wide geographical range of the Order Cycadacex during Jurassic times - an order now somewhat limited to tropical and subtropical climes, and which has only continued to exist in one of these areas-namely that of South Africa.

Of the four species of Pecopteris, one is not satisfactorily distinct from $P$. lobata of India; and two others are closely allied to P.Indica, also from the Jurassic plant-beds of the Rajmahal Hills.

In reviewing the few species of this ancient flora of South Africa, one cannot fail to be struck by the paucity of species in proportion to the abundance of specimens; and though limited in numbers, as the distinct forms are, yet there can be no doubt of their Jurassic character, seeing that some of the species are comparable with certain others from the Jurassic series of England and India. Thus Paloozamia recta, P. Rubidgei, Pecopteris Atherstonei, P. Rubidgei, and Sphenopteris antipodum represent, as it were, Palocozamia lanceolata, Zamites lanceolatus, Pecopteris Indica, and Sphenopteris Fulgeri of the European and Indian Jurassic rocks; whilst Asplenites lobata is common to these Indian and African strata: and though with one exception they are distinet, yet on the whole the Jurassic Plants of South Africa recall those of Scarborough and the Rajmahal Hills.

The following Table exhibits the affinities of some of the African species :-

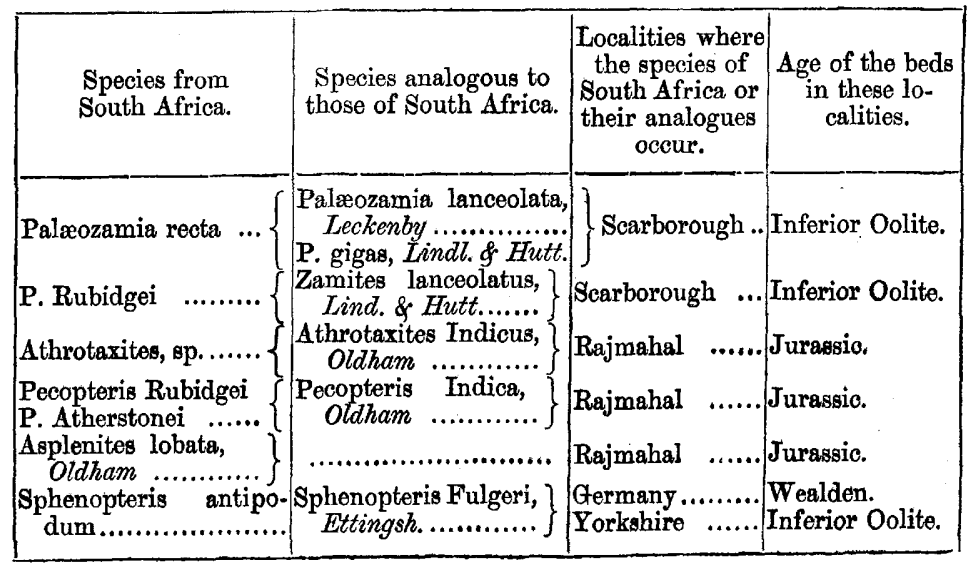




\section{c. Synopsis of the Uitenhage Series.}

The Jurassic strata are well seen in the Uitenhage district, and may therefore with propriety bo designated the "Uitenhage Formation" for convenience of reference. They are exposed by the rivers traversing the several basins of these rocks in the Eastern Province, especially in the upper part of the Bushman River, and the lower parts of the Sunday's, Koega, Zwartkop, and Gamtoos Rivers. The strata differ somewhat in the several basins. The following comparative Table of this Uitenhage series has been compiled chiefly from Dr. W. G. Atherstone's " Lecture on the Geology of Uitenhage," in the 'Eastern Province Monthly Magazine,' vol. i., 1857.

\section{Zwartkop River.}

8. Yellowish sand (greengrained) and calcareous rock, with gome bands made up of fossils (upwards of 100 feet thick, krauss").

Disintegrated rock ... fit. in

Hard ferruginons rock, very rich in fossils (Trigonia \& \& ) ....... 16 Bandstone .................. 164 Sandstone : fossils ... 16

Sandstone

Greyish sandstone

(all the sandstones

of this series are

more or less glau-

conite): fossils in

its lowest beds ......660 0

Trigonia band .......... 40

2. $(d$ and $c \rho$. ' Lignite at Bethelsdorp, \&oc.).

b. Fossiliferous dark ferruginous sandstone $\dagger \mathrm{COs}^{-}$ trea \&c.), in bands a few inches thick, alternating with aliferous shales and sandstones I (Atherstone).

Friable grey sandstone (alternating with ferruginous nodular bands, 1 foot thick), 20 feet. Greyish hard band, full of small Shells, mostly crushed, such a Dentalium, Turritells Ostrea, Nucala, and Astarte(?), with Cidaris gpines: 3 or 4 inches 6 .

$a$. White and rariegated sandstone (in the upper nart of the Zwartkop River). The "Zwartkop Sand stone" of Atheratone.

1. Quartzose pebbles, loomely proked in red clay and sand, 300 feet. The "Enon Conglomerate," Atherutone. Unoonformable on quartaite and schist.
Sunday's River.

3. Greenish-grey, calcareous, sandy, green-grained, fossiliferous rock (Bometimes limestone, sometimes andstone ग).
2. d. Light-brown sandstone, with lignite, jet, amber, and large reptilian bones. c. Grey sandy beds, with upright trunks of coniferous trees, and leaves of Zamim and Ferns, and comtaining two blue argillo-calcareous bands, rich with Ferns, also thin seams of lignite. $b$. Thin oysterbands, alternating with thin sandstones and saliferous shales, with gypsum. $a$. Hard grey and brown sandstone. This part of the formation (2a-d) is the "Wood-bed series," as seen at Geelhoutboom, where the Witwater joins theSunday's River.

1. The "Enon Conglomerate," lying unoonformably on old slates and sohists.
Bushman River.

3. Red, purple, and yellow marls and olays (130 feet and more).
2. Brown pebbly greengrained sandstone, with numerous prostrate treetrunks (some calcareous, some lignitic), drifted and bored by Gastrochmena, and bones of great Reptiles, including one with teeth like those of the Iguanodon. This is the "Wood-bed sertes" of Atherwtone, and is here perhaps 500 feet thick.

* Quart.1 Journ. f Geol. Boc. vol. vii. Miscel. p. 121, a translation from the Nova Acta Acad. Carol.-Leop. vol. xxi. part 2. p. 439 et seg. See also Trans. Geol. Soc. 2nd ser. vol. vii. p. 201. $\dagger$ On the Koega River also.

I This is the rock terned "Lowest Strata of the Zwartkop Crag" in the Tranc. Geol. Soc 2nct ser. vol. vil. p. 203. Krauss, loc. cit.

II Also on the Aamtoos River. These strats, $2 a$, of the upper part of the Zwartkop basin may be equivalent to a portion of $2 b$ of the lower part of the river.

I See Trans. Geol. Soc. 3nd got. vol. vii.p. 201. Theoe beds ("No. 3") and their equivalents mat be termed the "Trigonia-beds."

* Mr. Bain's section and remarks at p. 58, vol. vii. of Trans. Geol. Soc. 2nd ser., appear to point also to this conglomerate, and some overlying portion of the "Wood-bed series," in Lower Albany, north of the Bushman River. 
d. Description of some Fossils from the Jurassic Strata, or "Uitenhage Formation," on the Sunday's and Zwartkop Rivers, South Africa.

Ammonites subarcers, spec. nov. Pl. VII. figs. $3 a, 3 b$.

Shell small, somewhat compressed, deeply umbilicated. Whorls 4, narrow, depressed, inflated laterally by the development of the tuberculose costæ. Last whorl ornamented with ten tubereules; ten costæ arise from the inner margin of the whorl; these are directed slightly forward, and bifurcate or trifurcate from a salient pointed tubercle in the middle line of the whorl ; the ribs proceeding from the tubercle are inflected forwards, and interrupted upon the middle of the back, terminating there in a slightly pointed tubercle, but are otherwise continuous with a similar bundle of ribs developed on the opposite side. Back convex, with a smooth, shallow furrow in the middle. Mouth large, rounded.

Dimensions. Diameter 75 inch; diameter of outer whorl $\cdot 3$ inch; thickness of outer whorl $\cdot 3$ inch.

Observations. - It is doubtful whether this be not a mere variety of $A$. anceps, Reinecke, of the Middle Oolites. I have not been able to compare it with a specimen of its size, or a figure of a young shell of that species; it differs from $A$. anceps in the more compressed form, and in the ribs ending on the back in tubercles. The species bears much resemblance to $A$. Hookeri, Blanford, of the Jurassic beds of Niti, India.

Loc. With Alaria coronata in a greenish-grey sandy limestone on the Sunday's River.

HaMites Africanos, sp. nov. Pl. VII. figs. $5 a-5 d$.

Shell presenting an elliptical section, slightly compressed at the sides; the undulating, oblique, encircling ribs are acute, very regular, and separated by deep furrows.

The five fragments in the Collection vary much in size, and consequently in the direction of their annular foldings. In the largest portion, which measures 1.7 inch in circumference, the uninterrupted rib has a slight eurvature on the ventral surface, rises with a gentle sweep, at an angle of $70^{\circ}$, to the back, forming there a slight tubercle, a little without the mesial line. In portions of less diameter, the ribs are not so oblique and acute.

Obs.-This species has the lobes of its chamber-partitions apparently as in Hamites, and not as in Ancyloceras; but the character afforded by the septal lines is not always reliable, and the differences between these genera are of a doubtful nature; and though I refer the African form to the more characteristically Cretaceous genus, yet I attach very little value to its presence as indicative of Cretaceous age, unless it be supported by more restricted genera.

Loc. In a greenish-grey sandy limestone at Prince Alfred's Rest, and in a greenish sandy limestone at Sunday's River Mouth (Rubidge). Dr. W. G. Atherstone, of Graham's Town, who has also sent a specimen of this Hamite to England, says (in a letter, dated 
June 16th, 1859), "I have found the Hamites in the same formation with the Trigonias, not in distinct beds overlying them."

Belemrites Africands, spec.nov. Pl. VII. figs. $2 a, 2 b$.

This Belemnite belongs to the section Canaliculati, species of which, though ranging from the Inferior Oolite to the Kimmeridge Clay, are eminently characteristic of the Lower Oolites. This species differs but slightly from $B$. Aucklandicus, concerning which Von Hauer writes that "it resembles so much the well known and widely spread B. canaliculatus that it is almost impossible to give a sufficient diagnosis of it."

If $B$. sulcatus be distinct from $B$. canaliculatus, then the former is decidedly the analogue of the South-African and New-Zealand species; for in both $B$. Africanus and $B$. Aucklandicus the ventral groove does not extend to the point, a character that allies them to $B$. sulcatus and separates them from $B$. canaliculatus. They both, however, differ from $B$. sulcatus in being slightly compressed from back to front, presenting sectionally a subquadrate outline, as in $B$. canaliculatus, and not from side to side as in $B$. sulcatus. But, on the other hand, the external aspect of the two antipodean species is that of the last-mentioned species.

A second extra-European species allied to B. Africanus is $B$. Grantianus, D'Orb. *, of the Oolites of Cutch, which Sowerby + referred to B. canaliculatus, Schloth., but which was regarded as distinct by the former author, who applied to it the specific name here adopted. This species has the form and the wide ventral groove of $B$. Africanus, but agrees with $B$. canaliculatus in having the furrow continuous to the point.

It does not appear, perhaps, allowable to admit of three species intermediate between the closely allied $B$. canaliculatus and $B$. sulcatus; yet I feel justified, from a careful comparison of specimens of all the species, in the course here pursued.

The relationships of these stand thus:-B. Grantianus is a subspecies of, or is closely allied to, $B$. sulcatus. (The sulcation is broader and deeper than in the European B.sulcatus.)

$B$. Africanus and $B$. Aucklandicus, the representative species of B. sulcatus, are allied, and pass, through B. Grantianus, to B. canaliculatus. These species might, if allowable, be expressed thus :-

$$
\begin{aligned}
& \text { B. antipodum, a. Aucklandicus. } \\
& , " \text { B. Africanus. }
\end{aligned}
$$

Belemnites Africanus is the only species that links the Jurassic fauna of South Africa to that of the Secondary rocks of New Zealand; which Von Hauer regards as either of Jurassic or of Lower Cretaceous age. They contain an Aucella, two Inocerami, and $B$. Aucklandicus, the only species comparable with a European form, the affinities of which have been pointed out; the genus Aucella is confined to the St. Cassian beds and the Oolites; and as a Triassic

\footnotetext{
* Prodrome, vol. i. p. 327. † Trans, Geol. Soc. 2nd ser. vol. v. p. 329.
} 
fauna is well represented in New Zealand, there is presumptive evidence that the strata which in that island are superior to the latter are of Jurassic age.

Loc. Sunday's River Mouth (Rubidge).

Alaria coronata, spec. nov. Pl. VII. fig. 7 .

Shell fusiform, whorls 5 or 6 , each with an acute, undulate, spinous, mesial carina; the last whorl with 2 subordinate, obtuse carinæ, which are somewhat rugulose, not spinous; whorls with alternately large and small transverse rugulose striæ, crossed by very fine oblique striations.

The wing and digitations are not preserved in this unique specimen.

Dimens. Length (excluding canal) $1 \frac{1}{2}$ inch, breadth (without the wing) 1 inch.

The genus Alaria *, eminently, but not exclusively, characteristic of the Jurassic rocks, contains no known species which can be confounded with the present one.

Loc. In light-grey sandy shell-rock on the Sunday's River, associated with Ammonites subanceps.

Turritelta Rubidgeana, spec. nov. Pl. VIII. figs. $6 a, 6 b$.

Shell turreted, spire elongated; whorls 8 , angular ; suture deeply impressed. Upper half of each whorl with two mesial carinæ, the superior carina tuberculate, the inferior one imperfectly so. Each whorl is ornamented with about twenty elevated oblique ribs, which proceed from the suture to the tubercles of the upper carina, are continued longitudinally to the ill-defined tubercles of the lower carina, and are there lost. The lower half of the last whorl with three or more angular carinæ.

Dimens. 35 inch in length; breadth of last whorl 125 inch.

Loc. Several specimens, collected by Dr. Rubidge in a very sandy shell-band, with Ostrea, Astarte, \&c., at Bethelsdorp Salt-pan. These belong to the "Lowest Strata of the Zwartkop Crag," probably a part of the "Wood-bed series" (see p. 149).

Patelia caperata, spec. nov. Pl. VII. figs. $1 a, 1 b$.

Shell interruptedly conical ; apex obtuse, excentric, and inclined to one side ; the base is elliptical, and the periphery is irregular and slightly sinuated; ornamented by numerous radiating ribs, which are a little irregular in direction, and appear but as wrinklings of the surface, crossed by close-set lines of growth, conformable with the edge of the shell, adding to that appearance which I have sought to express by the specific title, caperata.

* In a short paper published in 'The Geological and Natural History Re* pertory,' on the so-called Rostellarice of the British Cretaceous Rocks, I have referred three species to the genus Alaria; Zekeli and Stoliczka enumerate five species from the Gosau formation as belonging to this genus; and thus eight species have been recorded from beds of Cretaceous age. 
Dimens. Length of longer diameter 2.8 millimetres; shorter diameter $2 \cdot 1$ mill.; height $\cdot 9$ mill.

Loc. In a reddish shell-rock, Prince Alfred's Rest? (Rubidge).

Chemantzia Africana, sp. nov.

Shell subulate, turreted; apex acute; whorls 9, very slightly constricted in their upper part; the longitudinal ribs, of which there are about twenty in a volution, arise from tubercles; the ribs are depressed and smooth, and become broader inferiorly. Suture deeply impressed ; aperture elliptical.

Length 7 lines.

This species is allied to Ch.(?) vetusta of the Great Oolite of England.

Loc. The specimen, which is unique, was obtained from the Zwartkop River.

Turbo Stowiands, spec. nov.

Shell turbinated, whorls convex; upper half of each whorl encireled by six bluntly acute ribs, alternating with similar smaller ones; lower half with the same ornamentation. Aperture round. Axis imperforate.

Dimens. Length 1.35 mill., breadth $\cdot 46$ mill.

T. Stowianus is related to T. Bainii, Sharpe.

Loe. Two specimens were collected by Dr. Rubidge at Prince Alfred's Rest.

AMpULLLARIA ? IGNoBdxis, spec. nov.

"Ampullaria ?, undetermined," Sharpe, Trans. Geol. Soc. 2nd ser. vol. vii. p. $203 \&$ p. 232 , pl. 28 . fig. 21.

Shell very minute, globular, apex subacute, spire very short, composed of 3 inflated whorls, last whorl almost enveloping the spire. Mouth oval.

Loo. Lowest strata of the Zwartkop Crag.

Phastakelta? Sharper, spec. nov.

"Natica, undetermined," Sharpe, Ioc. cit. pl. 28. figs. 2, 3.

Shell very minute, ovate, globose; spire short; whorls 3 , narrow, conrex; last whorl large; aperture large and round.

Loc. Lowest strata of the Zwartkop Crag; and Sunday's River.

Actaonina Morrisiana, spec. nov.

"Ampullaria ?, undetermined." Sharpe, 7oc. cit. pl. 28. fig, 20.

Shell very minute, ovate, cylindrical, apex acute; spire short, conical, composed of four cylindrical whorls, the last of which occupies $\frac{10}{11}$ of the whole length of the shell; aperture ovate-oblong, rounded in front, acute behind.

The species is named in compliment to Prof. J. Morris, F.G.S.

Loc. Lowest strata of the Zwartkop Crag. 
Actanonina Sharpeata, spec. nov.

"Cylindrites?, undetermined." Sharpe, loc. cit. pl. 28. f. 24.

Shell very minute, truncated, cylindrical; spire depressed, obsolete; vertex large, flattened; last whorl with somewhat inflated sides, base contracted, short; aperture elongated, moderately expanded towards the middle, subacute at the extremities.

Loc. Associated with the above.

Actzonina Jenktnstana, spec. nov.

"Actcoon?, undetermined." Sharpe, loc. cit. pl. 28. fig. 25.

Shell minute, elliptical; apex acute; spire of four whorls, elongated, regularly conical ; aperture elongate, attenuated before and behind.

Loc. Lowest strata of the Zwartkop Crag, and Sunday's River. OstreA."(Exogrra) Jonestaxa, spec. nov. Pl. VIII. figs. $3 a-3 c$.

Shell ovately orbicular, depressed, the larger valve only known, with a large adhering surface, or simply attached by the small involute umbo. Attached valve with a few strong and somewhat rounded ribs, which indent the margin.

Dimens. Length 1.57 mill., height 1.37 .

This species belongs to the section Exogyra, and but for that might have been referred to Ostrea costata of the Lower Oolites of Europe.

Loc. Salt-pans of Bethelsdorp, with Cidaris Africana (Rubidge).

Ostrea mmbrtcata, Krauss, sp.

The species Exogyra imbricata, Krauss, was referred by Sharpe to the genus Gryphaea; I have placed it in that of Ostrea, because the numerous specimens in the Society's museum exhibit gradations from one to the other of the so-called genera; in fact this species affords a good illustration of the mere sectional value (which cannot at all times be employed) of the groups Exogyra and Gryphoea.

The gryphoid form of Ostrea imbricata is closely related to an undescribed species of Gryphaec from the Oxford Clay of Weymouth.

Loc. Sunday's and Zwartkop Rivers.

Placunopsis imbricata, spec. nov. Pl. VIII. fig. 7 .

The unattached valve only is known; it is thin, ovate, oblique, and convex; the apex is acute and marginal; the dorsal margin of the valve is straight; the surface has concentric imbricating lamellæ, which towards the front of the valve occupy the ridges of the smooth undulations.

Dimens. Length 2.45 mill., height 1.64 mill.

The general aspect of this species is that of $\mathrm{Pl}$. semistriata, Bean, of the Cornbrash of Yorkshire; but the ornamentation of the shell of that species is very distinct.

Loc. In a brick-red shell-rock. One specimen from Prince Alfred's Rest (Rubidge). 
Placunopsis subjurensis, spec. nov. Pl. IX. figs. $1 a, 1 b$.

Shell orbicular, irregular, thin; free valve rather oblique, exceedingly gibbous; umbo submarginal, obtuse, and depressed; ornamented by numerous, fine, regularly nodulous, waved costæ, crossed by numerous delicate concentric striæ, and a few well-marked lines of growth.

Dimens. Length $1 \frac{1}{8}$ inch. Height $1 \frac{1}{4}$ inch.

The species of the genus Placunopsis have such a general resemblance one to another, both in form and ornamentation, bcing moreover necessarily more or less variable in shape, that it is often difficult to recognize constant distinctive characters. The present species has for its representative $P$. Jurensis of the Lower Oolites of Europe, and differs from it in its greater gibbosity and obliquity, and in possessing regular knotted ribs.

Loc. Collected by Dr. Rubidge in some abundance at the Zwartkop River Heights, in a yellowish sandy shell-rock.

Pracunopsis undotata, spec. not. Pl. IX. fig. 2.

Shell orbicular, thin, irregular, nearly equilateral ; convex, gibbous or depressed ; apex marginal, obtuse, and depressed, ornamented by numerous concentric waved rugæ.

Dimens. Length $1 \frac{1}{5}$ inch ; height $\frac{8}{10}$ of an inch.

Loc. In yellowish-grey limestone, Mouth of Sunday's River (Rubidge); and four specimens adherent to a piece of mineralized wood (calcareous with glauconitic grains) perforated by Gastrochona dominicalis*, Sharpe.

Pecten Rubidafanus, spec, nov. Pl. VII. fig. 11.

Shell inequivalve, ovately orbicular, convex, with nine or ten equal, large, elevated, subacute and distantly arranged costr; the intervals are wide and ornamented with very fine concentric strix, which are continued over the ribs. Auricles large and unequal.

Dimens. Height $\frac{7}{20}$ of an inch; breadth $\frac{6}{20}$ of an inch.

This Pecten presents the appearance, less the spinous processes, of $P$. subspinosus, Schloth., which ranges from the Inferior Oolite to the Coralline Oolite of Nattheim; other slight differencescan bo pointed out.

Loc. Dr. Rubidge has found this Pecten to be one of the most frequently occurring sholls, in a yellowish sandy shell-rock with greenish-grey patches here and there, at Prince . Llfred's Rest.

Pecten projectus, spec. nov. Pl. IX. fig. 6.

Shell oblique, ovately orbicular, moderately convex, equivalvo; remarkably inequilateral, the umbone being slightly curved anteriorly and the anterior side projected forwards. Valves ornamented with closely arranged dichotomous lines curving outwards; the interstitial spaces subpunctated. Auricles unequal, the anterior one

* The specimen figured in Geol. Trans. 2nd sar. vol. vii. pl. 23. fig. $4 a$, is wood, and not "bone," as stated at p. 198 , op. cit.-T. R. J.

VOL. XXIII.-PART I. 
large and concentrically rugose ; the posterior one small, the striations of the valve are continued upon it.

Dimens. Height $\frac{7}{8}$ of an inch; breadth $\frac{4}{5}$ of an inch.

$P$. projectus is closely related by its general outline and ornamentation to $P$. lens, Sow., and P. arcuatus, Sow., of the Lower and Middle Oolites of Europe; but the obliquity of the shell and the relatively excentric position of its apical portion are characters by which $P$. projectus is at once separated from them.

$P$. projectus is allied in form to an undescribed species which I have collected in the upper beds of the Inferior Oolite at Cold Comfort, near Cheltenham, and which I propose to call P. Tylori; the latter, however, is more depressed and smooth, except near the margin, where the shell is concentrically striated and crossed by radiating sharp indonted lines. P. Tylori is a shell that has been confounded, I believe, with $P$. cinctus, Sow., which belongs to the Lower Greensand and not to the Inferior Oolite.

Loc. Collected by Dr. Rubidge in a soft, yellowish-grey, sandy limestone at the Zwartkop River Heights, and at Prince Alfred's Rest; in both localities it is frequent.

Lima neglecta, spec. nov. Pl. VII. figs. $5 a, 5 b$.

“Lima, sp. (undeterm.)," Sharpe, Trans. Geol. Soc. 2nd ser. vol. vii. p. 201 (1856).

Shell oblong, transverse, slightly convex, ornamented with numerous acute ribs, the sides of which are longitudinally striated, two or three stronger striæ occupy the central portion of the interspace; under a magnifying glass the surface is seen to be covered with closely set, regular, transverse striations.

Dimens. Height $\frac{3}{8}$ of an inch, breadth $\frac{4}{8}$ of an inch.

L. neglecta belongs to a section of the genus exemplified by $L$. duplicata, Sow., in the Oolites, and L. parallela, Sow., in the Lower Greensand.

Loc. In a grey, coarse-grained, sandy and shelly limestone, Sunday's River (Atherstone).

Lims obliatissima, spec. nov. Pl. IX. fig. 5.

Shell elongated, depressed, very oblique, umbo acute; hinge-line obliquely truncating the shell; the whole surface ornamented with narrow waved sulci, interspaces punctated.

Dimens. - Height 1 inch; breadth $\frac{7}{8}$ of an inch.

In its elongated and oblique form, $L$. obliquissima resembles several Jurassic Lima ; in the character of its sulcations it approximates to $L$. rigidula, Phil.; in its punctated surface it is allied to L. ovalis, Sow.; it is, however, characterized by the broad and flat ribs, and the narrow interstitial spaces, angularly waved and punctated.

Loc. In a yellow shell-rock from the Zwartkop River Sandstone, and with Placunopsis undulata and fossil wood (Rubidge). 
Mrtilus Jonesr, spec. nov. Pl. VIII. figs. $4 a, 4 b$.

Shell nearly triangular,smooth, shining; hinge-margin straight and long; anterior margin elevated in its median portion ; umbo terminal, acute, depressed, ornamented with closely arranged, imbricating, concentric folds.

Named in compliment to Prof. T. Rupert Jones; who has taken part in the elucidation of the geology of South Africa, and whose kind assistance I gratefully acknowledge.

Dimens. Greatest length 1.9 millimetre; greatest breadth 1 millimetre.

Loc. In a greenish, coarse-grained sanảstone with calcareous cement, Sunday's River (Rubidge).

Mrtilus Srowianos, spec. nov. Pl. IX. figs. $3 a, 3 b$. [Subgenus Lithodomus.]

Shell pod-shaped, cylindrical, elongated, rather depressed, umbones small, contiguous, slightly inflated, anterior side narrow, posterior side wider and less compressed, upper and lower margins straight and nearly parallel; concentric plications few and delicate; radiately striated.

Loc. In a fine-grained, grey, sandy limestone, Sunday's River (Atherstone and Rubidge).

Mytudus RuBIDaei, spec. nov. Pl. IX. fig. 11, [Subgenus Modiola.]

Shell transversely elongated, with a straight dorsal edge; anterior part narrow and curved; posterior tapering at the end, divided into two portions by a very obtuse angle; superior and posterior part with numerous oblique plications, which are continued to the keel, and numerous slender folds which are coincident with the plications, but on reaching the keel continue parallel to the ventral margin.

Dimens. :- Total length ........... 5.25 millimetres.

Length of posterior side ... $5 \cdot 18$,

Height $\ldots \ldots \ldots \ldots \ldots, 0.9$

This shell is very distinct in its ornamentation from Modiola Bainii, Sharpe; but in that respect has a greater resemblance to Mytilus Sowerbyanus, D'Orb.; both, however, are straighter shells than M. Rubidgei.

Loc. In the greenish sandy limestone of the Sunday's River; many specimens (Rubidge).

Astarte Pinchintana, spec. nov. Pl. IX. figs. $7 a, 7 b$.

Shell small, ovately orbicular, depressed; umbo acute, postmesial, but direeted somewhat forwards; anterior side rounded, its upper margin slightly excavated; hinge-line straight and oblique; lunule small ; ornamented by obtuse, closely arranged, regular rugæ, which are slightly undulated on the anal-side; the interstitial spaces very narrow.

Dimens. Height and lateral diameter equal, or about 1.45 millimetre. 
PROCEEDINGS OF THE GEOLOGICAL SOCTETT. [Feb. 6 ,
[

This species has considerable resemblance in form and ornamentation to $A$. pumila, Sow., and $A$. excentrica, Morr. and Lycett, but differs in its larger size, greater obliquity and straightness of the cardinal line, and in the more excavated dorsal margin of the anterior side. This species is dedicated to Mr. Pinchin, a brother-geologist, from whom Dr. Rubidge has received much assistance in his researches.

Loc. In a grey sandy limestone, weathering yellowish, Sunday's River (Rubidge).

Astarte Longlandstana, spec. nov. Pl. VIII. figs. $5 a, 5 b$.

Shell obovate, slightly convex ; anterior side rounded, front curved, posterior side angularly truncated, hinge-line nearly straight or slightly arched; umbones depressed, obscure; lunule lanceolate; ligamental pit narrow and deep, bounded by sharp edges that nearly approach each other. Valves nearly flat, ormamented with numerous subacute, equidistant, slightly elevated ridges of growth.

Dimens. Length 3 inches, width $2 \frac{1}{4}$ inches, thickness $\frac{3}{4}$; length of anterior side 1 inch, of posterior 2 inches.

Loc. The unique specimen was found by $\mathrm{Mr}$. H. Longlands (to whom the species is dedicated) in a shelly band of the Zwartkop River limestone, October, 1859.

Pinata Sharpet, spec. nov. PI. IX. fig. 4.

A drawing* of a Pinna found by Mr. Pinchin is comparable with the figures of $P$. cancellata, Morris and Lycett, and $P$. Galliennei, D'Orb.; but as a description on such material must be incomplete, I merely reproduce the drawing, and propose the specific name of Sharpei, in memory of the late Mr. D. Sharpe, who described a former series of South-African fossil shells.

Loc. Sunday's River.

Trigonta Cassiope, D'Orb.

Shell ovately trigonal, longer than wide, depressed ; umbo anterior, prominent, acute, recurved; the anterior border is rounded; the posterior is truncated, with a large oblique flattened area, which is plicated by close-set, longitudinal, denticulated ribs; the dorsal surface has twenty large, smooth, gracefully curved costæ, separated from the curved, smooth (?) keel by a transversely wrinkled narrow sulcus. inch.

Dimens. Length 2 inches, width $1 \frac{1}{2}$ inch, length of carina $1 \frac{3}{4}$

This costated Trigonia approaches closely the well-known $T$. costata, from which it is distinguished, however, by the greater length proportionate to the width of the shell; the front also is more curved, and the posterior area is less oblique. T. costata is represented in the Scindian Oolites by the varieties pulla and elongata, the formcr of which is closely related to $T$. Cassiope. I unhesitatingly refer the African shell to this European species, which

* Made by Mr. Stow, and presented by him to the Geological Society. 
occurs in the Great Oolite of Luc (Calvados), Vezelay (Yonne), Grange-Henry, near Nantua, France*, and is moderately abundant in the Cornbrash of Yorkshire

Loc. Zwartkop River (Mr. H. Longlands). The specimen is unique.

Trigonia vat, Sharpe (juvenis), et T. ventricosa, Krauss, sp. ( juvenis). Pl. VII. fig. 8.

The character of the ornamentation clearly underwent a continuous change during life in these two species of Trigonia (T. vau and $T$. ventricosa); I have therefore thought it necessary to figure these species in their earliest stage of growth.

Trigonia GoLdfussr, Ag. (juvenis). Pl. VII. fig. 6.

Associated with the foregoing is the probably young shell of $T$. Goldfussi, Agassiz : certainly I should not be justified in assigning it another appellation; for the African shell is identical with figure $18 a$, plate v. of Morris and Lycett's 'Monograph of the Great Oolite Mollusca.' Hereafter, however, it may be found to be the young of a distinct species.

Loc. In a yellowish sandy shell-rock (a mass of Bivalves with green and grey sand) on the Sunday's River (Rubidge).

Corbtela? Rochiama, spec. nov. Pl. VIII. fig. 8.

Shell subglobular, smooth, shining ; umbones large, obtuse, mesial, erect; anterior side rounded; lunule large, concave; posterior side very short, with a well-marked oblique carina and a truncated posterior border; the surface has numerous, delicate, irregular folds of growth.

Obs.- The above diagnosis is nearly word for word that of Corbula Agatha, D'Orb., as given by Lycett in his 'Supplement to the Great Oolite Mollusca,' p. 65. That species, however, is of minute size ; its posterior side has a faintly marked carina, and its surface a few folds of growth.

Dimens. Length 1.19 millimetre, breadth 1.04 millimetre.

Loc. In a yellowish-grey - sandstone with calcareous cement, Zwartkop River (Atherstone and Rubidge).

Obs.-The dentition of Corbula? Rockiana is unknown; and the species may hereafter be found to belong to Isocardia or to Cyprina; but, on account of its close affinity to Corbula Agathr, I prefer to let it remain with that generic title.

The species is dedicated to Major Rock, who, with Mr. Stow, collected and communicated several fossils from the Uitenhage Formation, and whose name I take this opportunity of associating with South-African geology.

* D'Orbigny, 'Prodrome,' vol. i. p. 308 (1850).

t Lycett, 'Supplement to the Mollusca of the Grat Oolite,' Palront. Soc. (1863), p. 49. 
Crassatelia complicata, spec. nov. Pl. IX. fig. 8.

Shell oblong, very much compressed, very inequivalve, the posterior side truncated; anterior side rounded; lip smooth or crenulated; Iunule ill-defined; umbo subacute, ornamented with acute costæ, which diverge from the umbo, the angles of the ribs succeeding each other in an oblique direction, a little anterior or posterior to the middle line of the valve; the set of costæ directed towards the anterior side are slightly reflected; the series directed towards the posterior side are straight, the superior costæ of which form another group of diverging ribs; the angles of these are more acute and are directed from the umbo; a few straight costro occupy the remaining portion of the anal area, and denticulate the hinge-line, which is straight.

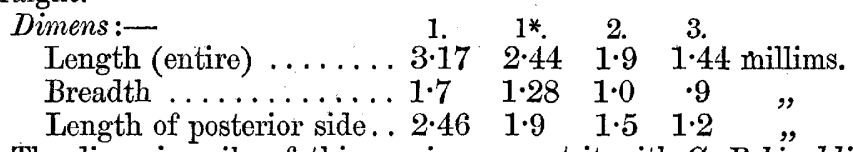

The diverging ribs of this species connect it with $C$. Robinaldina, D'Orb. *, of his "Néocomien inférieur" of the Parisian basin, and serve to distinguish it from all other species of the genus. $C$. complicata differs from its European representative in its straighter hinge-line, its truncated posterior side (in C. Robinaldina the anal side is slightly acuminated), in its more arched anterior side, and in having only about one-half the number of ribs. These two species present in their remarkable ornamentation a wide departure from the genus, the greater number of species of which have smooth shells; in others they are concentrically furrowed.

Species of the genus characterize tropical seas, and they are well represented in the Tertiary deposits in various parts of the northern hemisphere. During the Cretaceous epoch they appear to have been fow in number, as not more than eight or nine are known ranging upwards from the lowest marine bed of that system.

The restricted range of the genus Crassatella favours the supposition that the Secondary fauna of Uitenhage may be of Cretaceous age; but the opinion that too much value must not be placed on an isolated case is confirmed by the discovery of a true Crassatella in the Inferior Oolite of Rodborough, near Stroud, England ; and though it be not of the type to which C. complicata belongs, yet the value of the genus as evidence of a Cretaceous facies is thereby lessened.

Loc. Sunday's River (Atherstone); and in a yellowish-grey sandy shell-rock at Prince Alfred's Rest (Rubidge).

Cyrricardia Niveniana, spec. nov. Pl. VII. fig. 10.

Shell elongated, subtrigonal; umbo placed anteriorly to the middle of the valve, rather elevated and subacute; anterior side rounded, its upper margin slightly excavated, its lower extremity pointed; the posterior side slopes obliquely downwards, and has an

* Pal. Franç. Terr. Crét. vol. iii. p. 75, pl. 264, figs. 10-13. 
imperfectly defined obtuse angle; it is ornamented with delicate, elevated, closely arranged and regular concentric rugæ.

This species is named after Mr. Niven, a fellow-worker with Dr. Rubidge in the geology of the Cape.

Dimens. Length $\frac{9}{10}$ of an inch, height $\frac{13}{2} \frac{3}{0}$ of an inch, length of posterior side $\frac{13}{20}$ of an inch.

Loc. In grey sandy limestone, Sunday's River.

Crprina Borcherdst, spec. nov. Pl. VIII. fig. 2.

Shell ovate-oblong, transverse, inequilateral, somewhat inflated ; posterior side angulated, the margin truncated; anterior side rounded; front margin slightly arcuate ; umbones large, oblique, slightly recurved; ornamented by irregular-sized and close-set lines of growth coincident with the margin. [Named in memory of the late Mr. M. Borcherds, Civil Commissioner at Fort Beaufort, who warmly assisted the late Mr. A. G. Bain in his early researches in SouthAfrican Geology.]

Dimens. Irength $4 \cdot 1$ millimetres, height $3 \cdot 1$ millimetres.

Loc. Zwartkop River (Rubidge).

Cocullafa (Macrodon) Atherstoner, Sharpe, sp.

Arca Atherstoni, Sharpe, Geol. Trans. 2nd ser. vol. vii. p. 196, pl. 22. fig. 10 .

If Cucullcea and Arca be regarded as generically distinct, then the former name should be applied to this species, as I have determined by an examination of the type specimen that the hinge-teeth are longitudinal towards the margin. It belongs to the group Macrodon.

Cucullasa Kraussir, spec. nov.

Cuculloca? cancellata, Krauss (non Arca cancellata, Sow., nec Cucullcea cancellata, Phillips).

As the above-quoted specific name given by Krauss to an Arcalike shell is preoccupied, not only for Area, but for Cuculloea, I propose the name "Kraussii" instead.

Very perfect specimens collected by Dr. Rubidge on the Zwartkop and Sunday's Rivers exhibit the hinge-characters of this species; its position in Cuculloea is incontestable.

Arca (CuculizaA ?) Jonest, spee. nov. Pl. IX. fig. 9.

Shell rhomboidal, convex; umbones slightly anterior to the middle of the valve, large, depressed, and approximate. Anterior side short, its margin rounded; posterior side with an acute carina, posterior to which is a slightly concave surface; the inferior margin is nearly straight. Radiating costæ flat, slightly nodulous; elevated upon the anterior and posterior portions of the valves; much larger, more distant, and acute upon the anterior side; decussated by numerous concentric lines and striæ.

Dimens. Height 1.2 millim.; length 1.8 millim.

Loc. In a greenish-grey sandy marl, rather hard and very calcareous; near the Bridge on the Zwartkop River. 
Cardita nuctroides, spec. nov. Pl. VII. figs. $8 a-d$.

Shell quadrangular, subglobose, ornamented with fine, closely arranged, radiating lines interrupted by a few crenulated regular plications and fine concentric striæ; umbones anterior, directed forwards, involute ; lunule small, flat.

Dimens. Length $\cdot 8$ millimetre, height $\cdot 58$, thickness $\cdot 73$.

Loc. Sunday's River (Rubidge). The matrix is a greenish coarse sandstone of quartzose and glauconitic grains with calcareous cement.

\section{Berenicea antipodud, spec, noy. Pl. VIII. figs. $1 a, 1 b$.}

Polyzoon encrusting, rampant, composed of a single layer of cells. Cells elongated, smooth, nearly cylindrical, but somewhat flattened, quincuncially disposed; terminal portions prominent. Peristomes circular, remote, and separated by about equal distances from one another. The bases of the cells subelliptical, of unequal sizes, irregularly arranged.

Obs.-Berenicea antipodum is allied to B. striata, J. Haime, of the Lias of Valière, in its elongated and distant cells, and in the great diameter of the peristome. The cells of the African species are smooth; while in B. striata they are striated, and are less regularly disposed.

$B$. antipodum is the only Polyzoon hitherto known in the Second ary rocks of South Africa.

Loc.-In a yellowish shell-rock, with grey patches here and there, Prince Alfred's Rest; encrusting Trigonia vau, and Placunopsis undulata, from the mouth of Sunday's River; collected by Dr. Rubidge.

IsASTREA RichardSONI, M.-Edwards \& J. Haime, var. nov. antipodum.

Corallum massive, or somewhat gibbous ; calices polygonal, very unequal in size, shallow, and separated by a moderately strong wall. Fossula distinct; no columella. Septa thin, unequal in size, and forming three cycles; the six primary cycles are much larger than the others, and become thicker near their inner edges; but sometimes the secondary cycles are almost as much developed.

Largest diameter of the calices one and a half line.

The African form of the species differs from the type only in the smaller size of the calices, thinner walls, and more gibbous state of the coral-mass. It is the first recorded fossil Coral from South Africa; one example only is known.

Isastraea Richardsoni occurs in the Inferior Oolite of England, and resembles in its general aspect $I$. limitata and $I$. explanulata of the Great Oolite of the Anglo-Norman basin.

Loc. Discovered by Mr. G. W. Stow in the Uitenhage formation on the Zwartkop River. 
Serpdta(Vermilia)Pinchintana, spec. nov. Pl.IX.figs.10 a, 10b,10c. "Serpula, sp. Large single tube" (Sharpe, Geol.Trans.l.c.p.202),

Tube round, partly attached by a slightly expanded surface; rampant; free portion straight ; surface with transverse irregular plications. The outer diameter of the free portion equals 84 millims.

The unattached portion resembles the same part of the tube of Serpula quadristriata, and of S. volubilis of the Oolites; but in each of these the fixed part is convoluted. It has close affinity to Vermilia ampullacea and $V$. antiquata of the Cretaceons rocks, but differs from the former in being very perfectly round, and from the latter by the absence of annular rings.

Loc. On Trigonia Herzogii, Sunday's Rirer (Bain and Atherstone); Sunday's River Mouth (Rubidge).

Selipdla Filaria, Goldfuss.

Sunday's River (Rubidge).

Serputa plicatilis, Goldfuss.

Sunday's River (Bain).

Cidaris pustulitfera, spec. nov. Pl. VIII. figs. $9 a, 9 b$.

The materials at my disposal, illustrative of this species, are many interambulacral plates, some with portions of the ambulacral areas, exhibiting the poriferous zones, and numerous primary spines.

The ambulacral areas are narrow, with two rows of small granules; poriferous zones narrow, pores circular, and the septum between the pores forming an elevated moniliform line.

Interambulacral plate (fig. $9 \mathrm{~b}$ ) large and thick; boss prominent, and its summit smooth ; the areola is elliptical, around the margin of which are a great number of closely set, imbricating, scrobicular granules, which diminish in size towards the edge of the plate. Interambulacral polar plates (fig. $9 a$ ) thin, the areolæ circular.

Primary spines cylindrical; margin of acetabulum smooth; head of spine with a prominent finely crenulated ridge; stem of spine cylindrical, covered with granules or spiny tubercles having a linear arrangement.

Loc. Saltpans near Uitenhage (Rubidge).

The species described above belongs to that type of the genus characterized by the smooth and uncrenulated bosses of the tubercles; species of this type exist at the present time, and are found in Tertiary and Cretaceous rocks; species of the type with crenulated bosses characterize Oolitic deposits. There are, however, some exceptions to these rules; and for the present the African species may be regarded as another exceptional example.

Fucomes cravatus, spec. nov.

"Fucoid?", \&c., Sharpe, op. cit. p. 202.

Frond cylindrical, dichotomous; branches one inch in length, nearly equal, clavate.

Loc. In grey sandy limestone, Sunday's River. 
The following Reptilian remains may be noticed among the fossils from Uitenhage.

1. A small serrated Tooth resembling some belonging to AcANтHорноurs (Huxley, Geol. Mag. vol. iv. p. 65, pl. 5. fig. 4). It was sent to the Geological Society several years ago by Dr. Atherstone. It is imbedded in a greyish sandstone (reddish in part) with calcareous cement, and is from the "Wood-bed Series."

2. A small and imperfect femur of a Lacertilian, from the $Z_{w a r t-}$ kop River Heights (Dr. Rubidge).

\section{e. General Remarks on the Fauna of the Uitenhage Formation.}

The collections of Jurassic fossils from South Africa acquired by the Society since the publication of Mr. Daniel Sharpe's descriptions of Messrs. Bain and Atherstone's specimens contain many new forms, and some few specifically identical with extra-African species. By the aid of these new materials, I have been enabled to arrive at a nearer approximation as to the age of the beds which have yielded them.

The donors to whom the Society is indebted for these valuable acquisitions are Dr. Rubidge, F.G.S., Messrs. Stow and Longlands, Major Rock, and Capt. Harvey.

The earliest publication of any fossils of Secondary (Jurassic) age from the Cape of Good Hope was by Hausmann in 1837; the two species mentioned by him were subsequently figured and described by Goldfuss. Krauss increased this number by the addition of 7 species. Mr. D. Sharpe added 22 species to those previously described; and the species added by the foregoing descriptions make up a total of 74 species for the Jurassic rocks of South Africa.

Krauss proposed to place the beds yielding Trigonia Hausmanni, Astarte Herzogii, \&c. in the Cretaceous series; and the evidence afforded by the few species at his command warranted that arrangement, the Trigonice having affinities with Post-jurassic species. But since then undoubted Cretaceous fossils have been discovered in Natal; and these have no affinity whatever with those found to the south in the Uitenhage district. The late D. Sharpe's opinion, that the Secondary fossils from this part of South Africa were comparable with those which are found in ' the middle and lower part of the Oolitic series,' is much strengthened by the nature of the additional material.

The great mass of the fossils are Bivalves, which constitute twothirds of the entire fauna, as far as known. Cephalopods are represented by six species; but individuals are rare; the Gasteropoda are fairly represented. A Berenicea, three Serpula, a Cidaris, and a Coral are the only representatives (as far as our collection serves) of the several classes to which they respectively belong.

The extreme rarity of the remains of Cephalopods, Polyzoa, Echinodermata, and Madreporaria calls to mind the conditions of life which prevailed during the deposition of the Great Oolite, and in a less degree of the Forest-marble and the Cornbrash, in this country. 
The generic grouping is such as obtains in the Jurassic strata; and though no genus present in the Uitenhage series is exclusively of that age, yet the following point to such an age :-Belemnites (of the section Canaliculati), Actceonina, Neritopsis, Alaria, Pleuromya, Placunopsis, Gervillia, and Isastroea.

The genus Alaria is eminently, but not exclusively, characteristic of Jurassic rocks; eight species, however, have been recorded from beds of Cretaceous age. I have no knowledge of the genus Placunopsis having ever been identified from rocks newer than the Lower Oolites, though its occurrence in the Coal-measures of Illinois has lately been recorded by Messrs. Meek and Worthen: and though Isastrcea ranges from the St. Cassian beds to the Tertiary, yet it is a good Jurassic genus.

On the other hand, Hamites and Crassatella, which are reprem sented in the Uitenhage beds, may be thought to indicate Cretaceous affinities; yet I attach very little value to their presence as indicative of Cretaceous age, unless they be supported by more restricted genera. Such a one apparently is Crassatella, which hitherto has not been met with below the Lower Greensand; and its restricted range favours the supposition that the Secondary fauna of Uitenhage, or a part of it, is of Cretaceous age; but that too much value should not be placed on an isolated case receives confirmation in the newly ascertained occurrence of a Crassatella ( $C$. oolitica) in the Inferior Oolite of England: the presence of the genus as marking a Cretaceous facies is materially lessened by this discovery.

The Uitenhage fauna under notice does not contain a single genus unknown in the Jurassic Series. Krauss, it is true, created the genus Anoplomya on South-African shells; but it is clearly synonymous with Pleuromya.

None of the fossils enumerated by the late D. Sharpe are identical with any known European species; but amongst those subsequently added to our collection are two European forms, Trigonia Cassiope, D'Orb., and T. Goldfussi, Agassiz. Serpula filaria and S.plicatilis are the other European species.

A very large number of the Jurassic Mollusca of South Africa have their representatives in the Oolites of Europe and the equivalent beds in India. The following Table exhibits those from Uitenhage which are analogous to Secondary species in other parts of the world. 
PROCEEDINGS OF THE GEOLOGICAL SOCIETY. [Feb. 6,
[

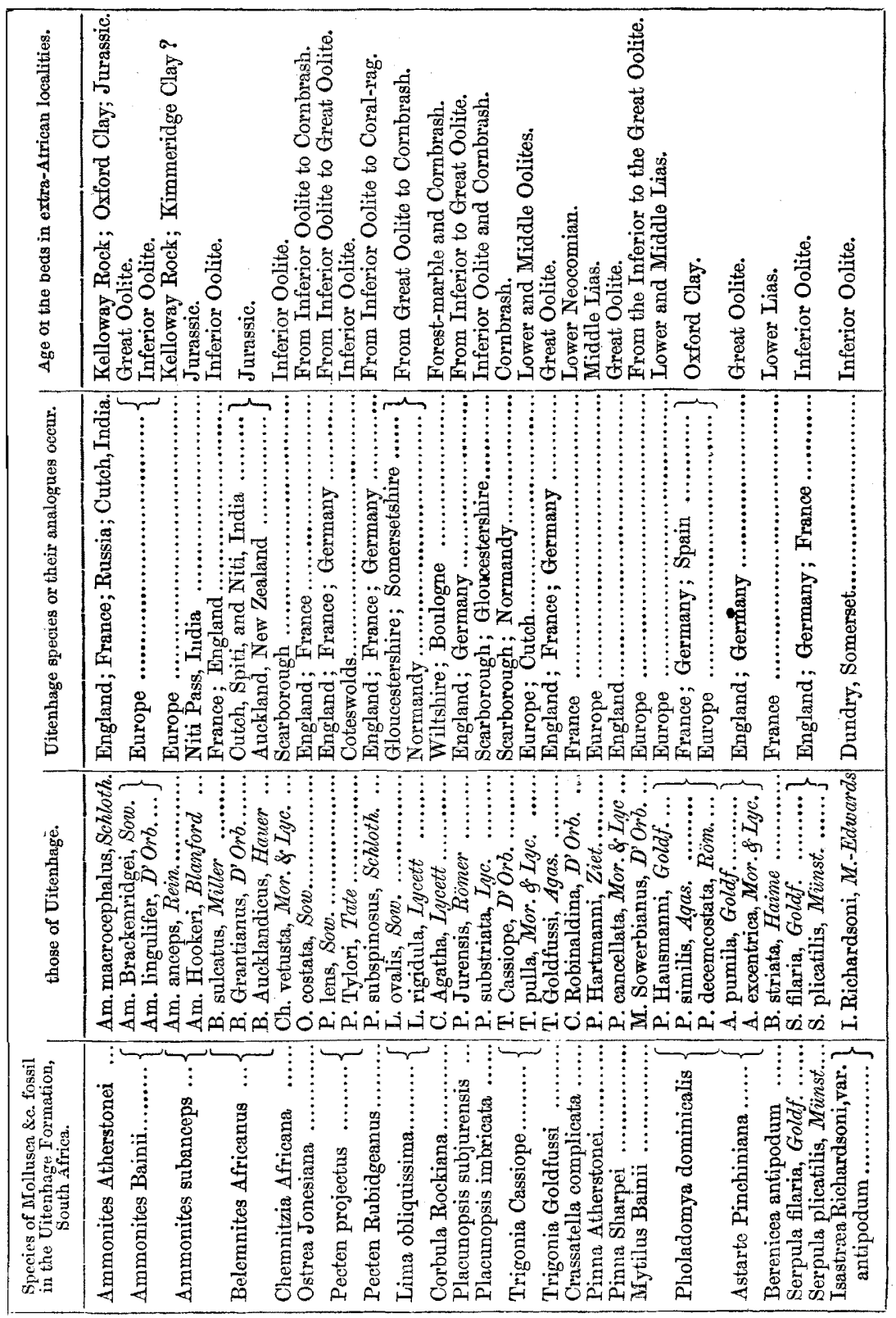


From the above Table the following conclusion may be deduced:-

That the fauna of the strata ('Trigonia-beds) overlying the plant-. bearing beds of Geelhoutboom presents a decided Oolitic facies ; and, though fow species are common to these South-African strata and the European Oolites, yet from the large number of species in these strata at Uitenhage having analogues in the Lower and Middle Oolites, and the species in common pointing in the same direction, the fossil fauna of the Sunday's River and Zwartkop River Limestones represents that of the Oolitic rocks of Europe, and approximates to that of the Great Oolite.

IV. Observations on the Secondary Strata of South Africa, and on their foreign equivalents.

The Secondary strata now determined for South Africa are as follows :-

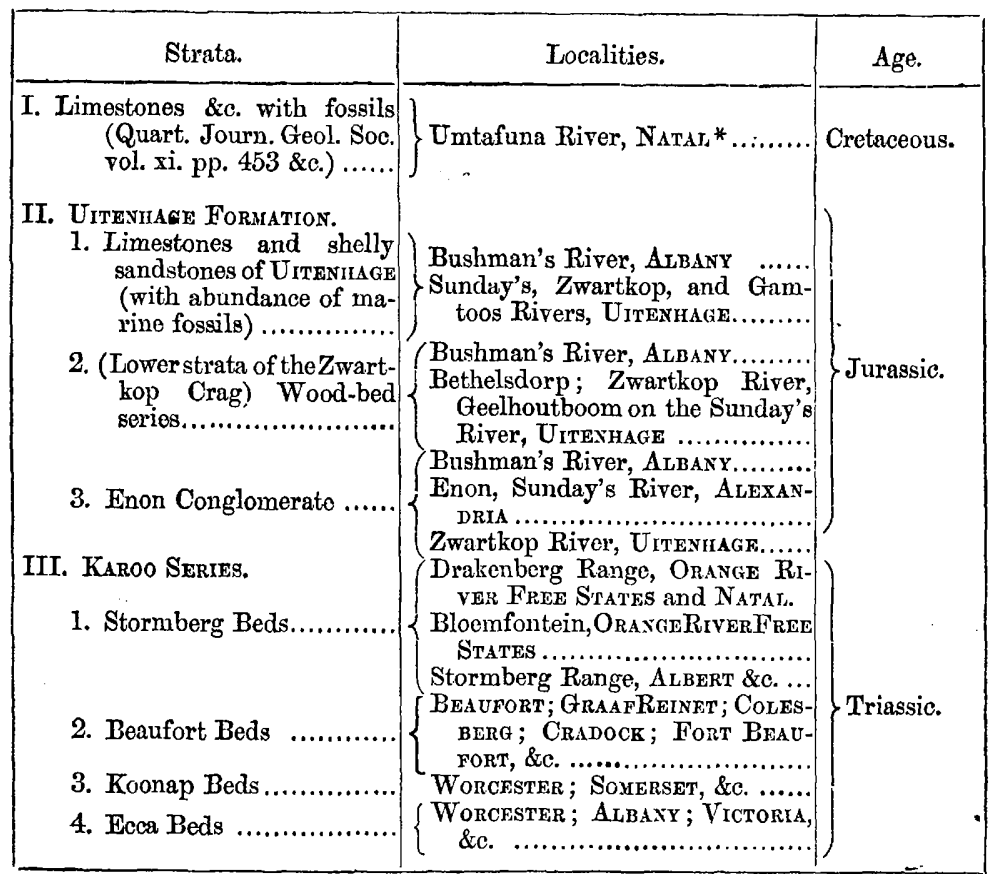

The study of the affinities of the fossils of Secondary age in South Africa has led me to consider the distribution of the lower members of the Mesozoic rocks over the surface of the earth, and the laws that apparently were in operation during their deposition.

The Upper Trias presents, in the majority of the countries in which it has been carefully examined, a renarkable uniformity with

* The names in capital letters are names of Provinces. 
the European type. In the Niti Pass* and Spiti Valley (N. W. Himalayas), New Zealand $\dagger$, California $\ddagger$, and Now Caledonia §, Triassic rooks have yielded many of the characteristic marine fossils of the Upper Trias of Austria, where this formation is typically developed. In South Africa, rocks of this age present somewhat exceptional characters; and if we regard the Keuper of Europe as indicating a condition of things approximating to fresh water or brackish water $\|$, the lacustrine deposits of the Karoo Desert will be analogous to it.

The Jurassic series, which has its fullest development in Western and Central Europe, is reduced, in the Mediterranean basin, to beds representing the Lower and Middle Jurassic beds, from the Lias to the Oxford Clay inclusive; and in Russia the Jurassie rocks constitute but one formation. In extra-European countries, containing representatives of the Jurassic rocks, there is, as in Russia, no division into formations as in Western Europe; and the fauna represents not that of one of these formations, but is equivalent to those of the various groups of rocks, recalling, however, on the whole, the forms of life prevalent in the Middle and Lower Oolites, as strikingly illustrated by the Jurassic fauna of Cutch, India, of that of the Niti Pass, of Thibet--in a less degree by that of New Zealand, and even that of Spiti ; for though Dr. Stoliczka has endeavoured to establish a definite succession of strata analogous to several members of the European Juras, yet, in my opinion, he has failed to establish a true correlation; for the fossils which in Europe belong to determinate stages in the geological scale are confusedly associated together in the various members of the Spiti equiralents of the Jurassic rocks. Trautschold divides the Jurassic rocks of Moscow into three zones; but in each occur fossils of various Jurassic formations, rendering it impossible to pronounce on the equivalent of any one of them. This appears to be the case with the Spiti beds. The marine Jurassic strata of South Africa do not show any evidence of a departure from the conditions that determined the distribution of life in extraEuropean areas during Jurassic times.

This remarkable world-wide distribution of the animal life of the Middle Jurassic rocks is paralleled by that of the associated vegetable remains T; for accompanying the Jurassic faunas of Cutch and Uitenhage are plants generically identical with those of the phytiferous beds of the Yorkshire coast, which occupy an horizon near to the base of the Lower Oolites, and contain the most complete flora of the Jurassic epoch.

This relationship of the faunas and floras of extra-European

* Mem. Geol. Surv. India, vol. v. pt. 1. p. 35 et seq.

$\uparrow$ Paläontologie von Neu-Seeland.

$\ddagger$ Palæontology of California, rol. i. p. $19 \mathrm{et}$ seq.

$\$$ Bull. Soc. Linn. Normandie, vol. viii. p. 332 et seq.

II See remarks on the Lettenkohle of the Keuper and on the Triassic deposits of Virginia, Connecticut, \&c., in Prof. Rupert Jones's 'Monograph of the Fossil Estherix,' Pal. Soc. 1862.

T The existence of Jurassic deposits on the east coast of Africa appears to be proved by the occurrence of Ammonites annularis, Rein., at Kisaludini, near Mombas, $4^{\circ}$ S. lat. (Quart. Journ. Geol. Soc. vol. xv. part ii. p. 17, 1859). 
Oolitic rocks to those of Europe shows an affinity and a correspondence in the northern and southern hemispheres which does not exist in the now-living faunas and floras, and demonstrates the contemporaneity of deposits having a wide geographical range; for, with but very few exceptions, the species in the several areas are distinct, whilst the majority of those in each of the several areas have analogous forms in the other areas; and they, as a whole, constitute but one type, approximating to that of the Lower and Middle Oolites. Is not the one formation in Cutch, in Uitenhage, and in Russia contemporaneous with the whole Jurassic period of Europe? for in this latter area, where the greatest variation of physical conditions has prevailed, there is to be found the greatest diversity of life. Now, if the condition of homotaxis had been in operation, a greater community of species between the faunas and floras of these outlying areas and those of the great centre of diffusion would have resulted. But little or no dispersion had taken place, as each of these provinces has its own fauna and flora, the amount of persistency of life in each corresponding to the uniformity of the forces which were in operation from the commencement to the close of the Jurassic epoch. Western Europe, having been the scene of great physical changes during this period, possesses a great variety of life, whereas South Africa during the same period of time witnessed few revolutions, and, as the forces tending to modify its life were comparatively tranquil, its fauna and flora exhibit little diversity.

I therefore would not regard the Oolites of South Africa as coeval with this or that formation, but maintain that they are the representations of the whole of the Jurassic rocks-or rather of the whole, less the Upper Oolites, since no forms analogous to those of that period have been met with beyond the confines of Europe.

It is also worthy of remark that the representative faunas of the European Cretaceous rocks, in the majority of the extra-European districts examined, exhibit a remarkable uniformity, and are analogous to the fauna of our Middle Cretaceous formations.

\section{A Table of the Organic Remains of the Uitenhage Formation.}

\section{a. Flora of the Wood-bed Series at Geelhoutboom.}

\section{Order Conifere.}

Athrotaxites Indicus?, Oldham.

\section{Order Cycadaces.}

1. Palrozamia (Otozamites) recta, Tate.

2. Palæozamia (Podozamites) Morrisii, Tate.

3. Palæozamia Rubidgei, Tate.

4. Palæozamia? Africana, Tate.

Order Finices.

1. Pecopteris Atherstonei, Tate.

2. Pecopteris Rubidgei, Tate.

3. Pecopteris Africana, Tate.

4. Asplenites lobata, Oldham.

5. Sphenopteris antipodum, Tate.

6. Cyclopteris Jenkinsiana, Tate. 


\section{b. Fauna of the Uitenhage Formation.}

\begin{tabular}{|c|c|c|c|c|c|}
\hline & 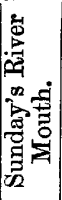 & 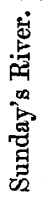 & 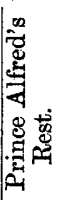 & 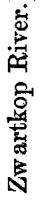 & 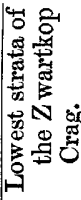 \\
\hline Acanthopholis? (Tooth.) ............. & $\ldots$ & $\cdots$ & $\ldots$ & $\ldots$ & *? \\
\hline Lacertilian bone $\ldots \ldots \ldots \ldots \ldots \ldots \ldots \ldots$ & ... & ... & $\ldots$ & * & $\ldots$ \\
\hline Ammonites Atherstonei, Sharpe ........... & ... & $*$ & $\ldots$ & * & $\ldots$ \\
\hline 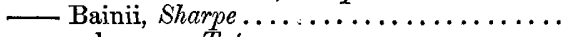 & $\cdots$ & * & ... & ... & ... \\
\hline 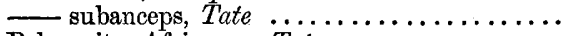 & $\cdots$ & * & ... & $\ldots$ & ... \\
\hline Belemnites Africanus, Tate............ & * & $\ldots$ & $\ldots$ & ... & $\cdots$ \\
\hline 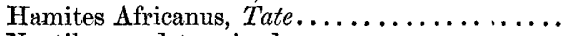 & * & ... & $*$ & ... & $\cdots$ \\
\hline Nautilus, undetermined $\ldots \ldots \ldots \ldots \ldots \ldots$ & ... & * & ... & $\ldots$ & ... \\
\hline Actæonina Atherstonei, Sharpe, sp. ........ & $\cdots$ & $*$ & ... & ... & $*$ \\
\hline 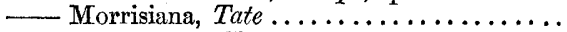 & ... & ... & ... & $\ldots$ & * \\
\hline - Jenkinsiana, Tate $\ldots \ldots \ldots \ldots \ldots$ & $\ldots$ & * & $\ldots$ & $\ldots$ & * \\
\hline 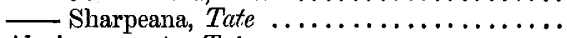 & ... & ... & $\ldots$ & $\ldots$ & * \\
\hline 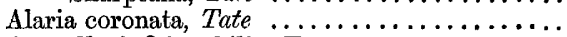 & ... & $\ldots$ & $\ldots$ & $\cdots$ & * \\
\hline 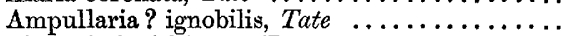 & $\ldots$ & ... & $\cdots$ & $\cdots$ & * \\
\hline 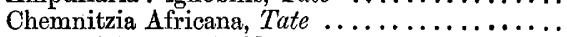 & $\ldots$ & $\ldots$ & $\cdots$ & * & ... \\
\hline Natica Atherstonei, Sharpe ............... & $\ldots$ & $\cdots$ & $\cdots$ & $\ldots$ & * \\
\hline Neritopsis turbinata, sharpe ............ & ... & * & $\cdots$ & $\cdots$ & ... \\
\hline Phasianella? Sharpei, Tate ............... & ... & * & $\ldots$ & $\cdots$ & * \\
\hline 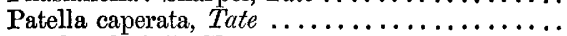 & ... & $\ldots$ & *? & $\cdots$ & ... \\
\hline Trochus Bainii, Sharpe $\ldots \ldots \ldots \ldots \ldots \ldots \ldots$ & $\ldots$ & $\cdots$ & $\ldots$ & $\cdots$ & * \\
\hline 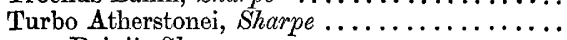 & $\ldots$ & $\ldots$ & ... & $\cdots$ & * \\
\hline 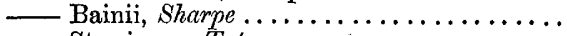 & $\ldots$ & * & ... & ... & * \\
\hline 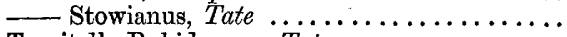 & $\ldots$ & $\cdots$ & * & ... & ... \\
\hline Turritella Rubidgeana, Tate $\ldots \ldots \ldots \ldots \ldots$ & $\ldots$ & $\cdots$ & $\ldots$ & $\ldots$ & * \\
\hline 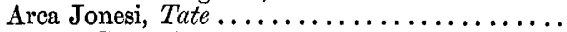 & $\ldots$ & ... & $\ldots$ & $*$ & $\ldots$ \\
\hline Astarte Bronnii, Krauss . . . . . . . . . . . . & $\ldots$ & ... & ... & * & $\cdots$ \\
\hline - Herzogii, Hausmann .............. & ... & $\ldots$ & $\ldots$ & $\hat{*}$ & $\ldots$ \\
\hline - Longlandsiana, Tate ........... & $\ldots$ & ... & $\ldots$ & * & ... \\
\hline - Pinchiniana, Tate .......... & $\ldots$ & * & $\ldots$ & ... & ... \\
\hline Avicula Bainii, Sharpe............ & $\ldots$ & $\ldots$ & $\ldots$ & $\ldots$ & * \\
\hline Cardita nuculoides, Tate........... & ... & * & $\ldots$ & $\cdots$ & $\ldots$ \\
\hline Ceromya papyracea, sharpe $\ldots . . .$. . & $\cdots$ & $\ldots$ & $\cdots$ & * & $\ldots$ \\
\hline Corbula Rockiana, Tate ........ & $\cdots$ & $\cdots$ & $\cdots$ & * & $\cdots$ \\
\hline Crassatella complicata, Tate ............ & $\ldots$ & * & * & $\ldots$ & . \\
\hline Cucullæa (Macrodon) Atherstonei, Sharpe, sp.. & $\cdots$ & * & $\ldots$ & $\cdots$ & $\cdots$ \\
\hline 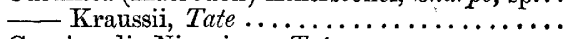 & ... & * & ... & * & $\cdots$ \\
\hline Cypricardia Niveniana, Tate ........ & $\ldots$ & * & $\ldots$ & $\ldots$ & $\cdots$ \\
\hline Cyprina Borcherdsi, Tate ............. & $\ldots$ & $\cdots$ & $\ldots$ & * & $\cdots$ \\
\hline$\mp$ rugulosa, sharpe ............... & $\ldots$ & * & ... & ... & $\cdots$ \\
\hline Cyrena ? Bainii, sharpe .......... & ... & $\ldots$ & ... & $\ldots$ & * \\
\hline Gastrochæna dominicalis, Sharpe ... & ... & *† & $\ldots$ & ... & .. \\
\hline Gervillia dentata, Krauss $\ldots \ldots \ldots \ldots$ & $\ldots$ & * & $\ldots$ & * & ... \\
\hline Lima obliquissima, Tate . . . . . . . & ... & $* \dagger$ & ... & * & ... \\
\hline neglecta, Tate ...... & $\ldots$ & * & ... & $\ldots$ & \\
\hline Mytilus Jonesi, Tate. . . . . . . . . . . . . & $\ldots$ & * & & $\ldots$ & ... \\
\hline - (Modiola) Atherstonei, Sharpe, sp. & $\ldots$ & $\ldots$ & ... & $\ldots$ & * \\
\hline - (Modiola) Bainii, Sharpe, sp. ........ & $\cdots$ & xt & $\ldots$ & $\ldots$ & \\
\hline — (Modiola) Rubirgei, Tate ............ & & * & $\ldots$ & $\ldots$ & $\ldots$ \\
\hline
\end{tabular}

† These seem to belong to the "Woodbed series" of the Sunday's River; and probably others of the same zone are included in this column. 


\begin{tabular}{|c|c|c|c|c|c|}
\hline & 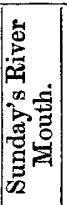 & 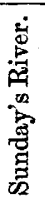 & 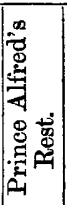 & 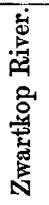 & 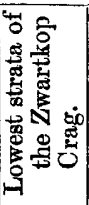 \\
\hline 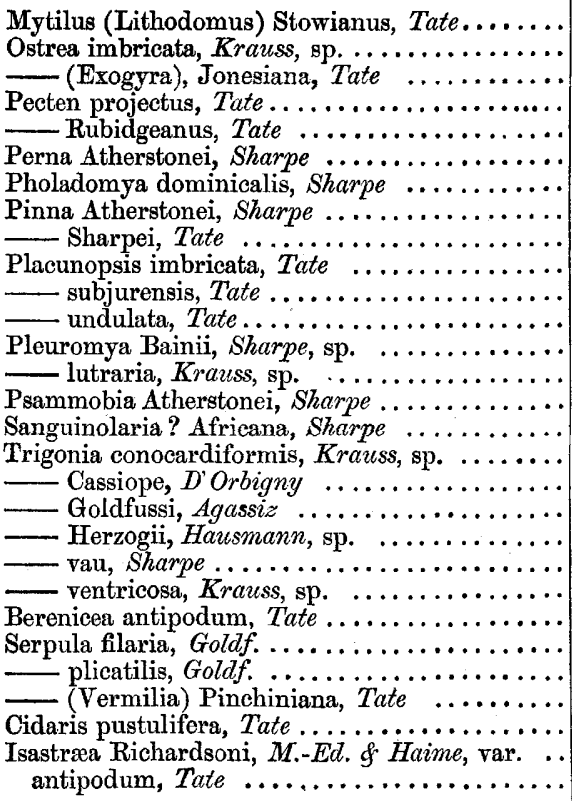 & 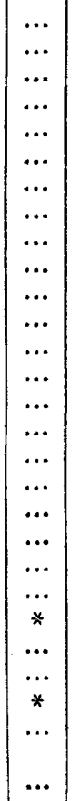 & $\begin{array}{l}* \\
* \\
\ldots \\
\ldots \\
\cdots \\
* \\
* \\
* \dagger \\
\ldots \\
\ldots \\
* \\
\ldots+ \\
* \dagger \\
* \\
* \\
\ldots \\
* \\
* \\
\ldots \\
\ldots \\
* \\
* \\
* \\
\cdots \\
\ldots\end{array}$ & $\begin{array}{c}\ldots \\
\ldots \\
\ldots \\
* \\
* \\
\ldots \\
\ldots \\
\ldots \\
\ldots \\
* \\
\ldots \\
\ldots \\
\ldots \\
\ldots \\
\ldots \\
\ldots \\
\ldots \\
\cdots \\
\ldots \\
\ldots \\
\ldots \\
\ldots \\
* \\
\ldots \\
\ldots \\
\ldots \\
\ldots \\
\ldots\end{array}$ & $\begin{array}{c}\ldots \\
* \\
\ldots \\
* \\
\ldots \\
\ldots \\
\ldots \\
\ldots \\
\ldots \\
\ldots \\
* \\
\ldots \\
\ldots \\
* \\
\ldots \\
\ldots \\
* \\
* \\
\ldots \\
* \\
* \\
* \\
\ldots \\
\ldots \\
\ldots \\
\ldots \\
\ldots \\
* \\
*\end{array}$ & $\begin{array}{c}\ldots \\
\ldots \\
* \\
\ldots \\
\ldots \\
\ldots \\
\ldots \\
\ldots \\
\ldots \\
\ldots \\
\ldots \\
\ldots \\
\ldots \\
\ldots \\
\ldots \\
* \\
\ldots \\
\ldots \\
\ldots \\
\ldots \\
\ldots \\
\ldots \\
\ldots \\
\ldots \\
\ldots \\
\ldots \\
* \\
\end{array}$ \\
\hline
\end{tabular}

Postscript.- Since compiling the synoptical accounts of the Karoo and Uitenhage formation given at pages $142 \& 149$, Dr. Atherstone has kindly sent me the 'Notes of a Journey in two directions across the Colony, made in the years 1857-58, by Andrew Wyley, Esq.,' 4to: Cape Town, 1859. This Report contains very valuable information on the lithology and geology of South Africa; and, as an Appendix, the author gives, in a tabular form, his views of the grouping of the several formations, with their approximate thicknesses, as below. I premise, however, that Mr. Wyley's reference of some of the divisions to the European New Red Sandstone and the Carboniferous groups is not at all in accordance with the views advanced in the foregoing Memoir.

Mr. Wyley's divisions of the Karoo Beds, with the included Trap-breccia, coincide with those suggested at pp. 142, 143; but his nomenclature appears to me less applicable than that proposed in this Memoir.

†These seem to belong to the "Wood-bed series" of the Sunday's River; and probably others of the same zone are included in this column.

VOL. XXIII.-FART I. 


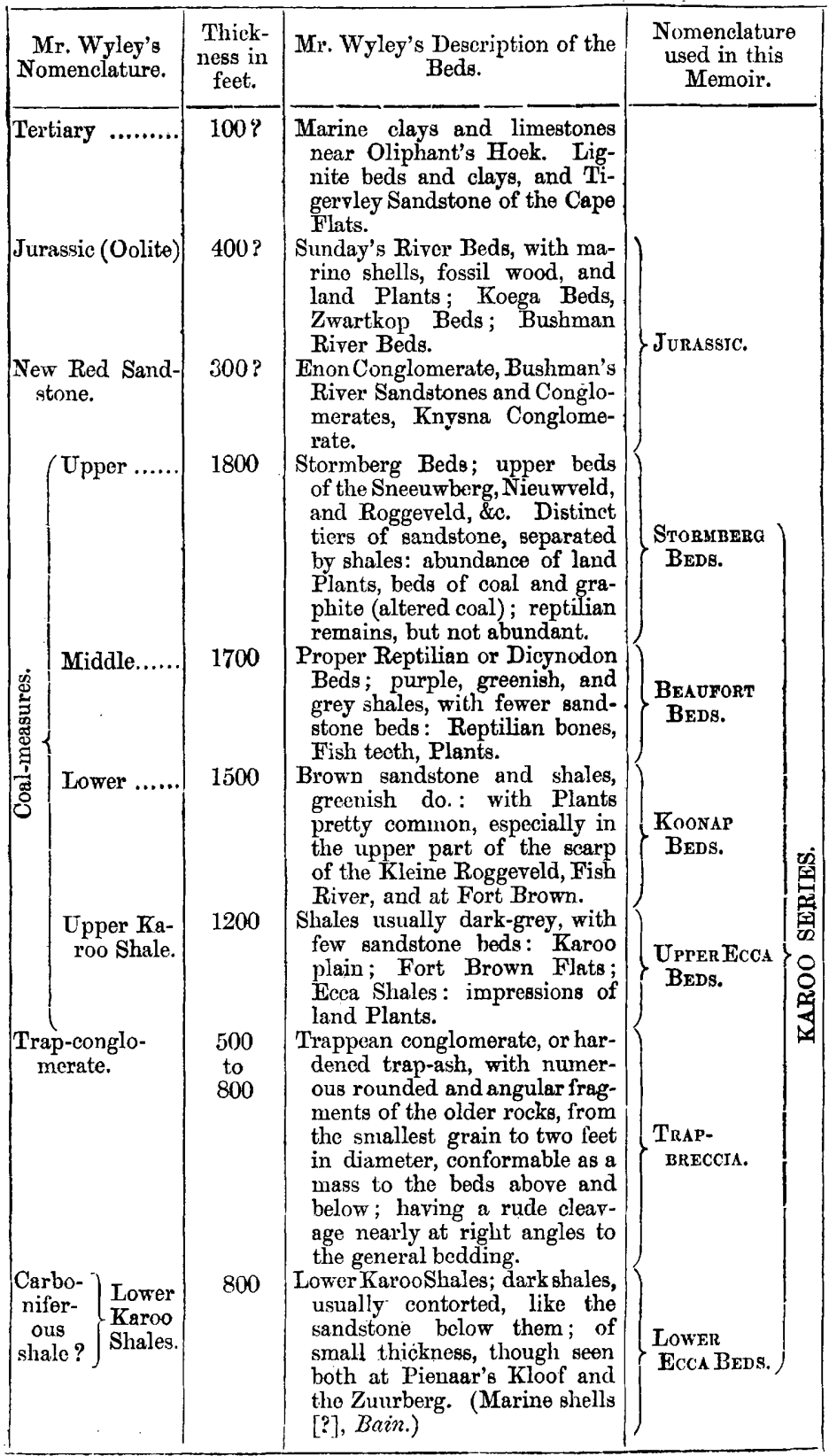




\begin{tabular}{|c|c|c|c|}
\hline $\begin{array}{l}\text { Mr. Wyley's } \\
\text { Nomenclature. }\end{array}$ & $\begin{array}{l}\text { Thick- } \\
\text { ness in } \\
\text { foet. }\end{array}$ & $\begin{array}{l}\text { Mr. Wyley's Description of the } \\
\text { Beds. }\end{array}$ & $\begin{array}{l}\text { Nomenclature } \\
\text { used in this } \\
\text { Memoir. }\end{array}$ \\
\hline $\begin{array}{l}\text { Carboniferous } \\
\text { Limestone. }\end{array}$ & 1000 & $\begin{array}{l}\text { Witteberg and Zuurberg, Gra- } \\
\text { ham's Town and Winterhoek } \\
\text { Sandstone. Sandstones of a } \\
\text { white or yellowish colour, a } \\
\text { few beds of red or yellow } \\
\text { shales. Plants, Lepidoden- } \\
\text { dron \&c. }\end{array}$ & \\
\hline 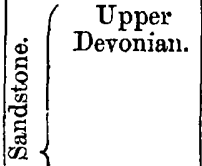 & 1100 & $\begin{array}{l}\text { Dark-grey and brownish shales, } \\
\text { with fossils abundant, of a De- } \\
\text { vonian or Carboniferous Lime- } \\
\text { stone type; beds of brown } \\
\text { rippled sandstone, with long- } \\
\text { winged Spiriferi. }\end{array}$ & \\
\hline \begin{tabular}{|c|c} 
& Lower \\
& Devonian. \\
&
\end{tabular} & 4000 & $\begin{array}{l}\text { Table-mountain Sandstone, and } \\
\text { sandstones of the littoral range } \\
\text { of mountains generally; grey } \\
\text { sandstones, conglomeratic at } \\
\text { base, reddish shaly below. }\end{array}$ & \\
\hline Silurian ....... & unknown & $\begin{array}{l}\text { Slate and grits, usually of a } \\
\text { greenish, grey, or brownish } \\
\text { colour; beds, as usually seen, } \\
\text { vertical, or at high angles, } \\
\text { broken through and altered } \\
\text { by granite. }\end{array}$ & \\
\hline Metamorphic ... & (......... & $\begin{array}{l}\text { Greiss, granitic gneiss, and me- } \\
\text { tamorphic schists, limestone, } \\
\text { \&c.; Namaqualand, Bushman- } \\
\text { land, Kalihari Desert, and a } \\
\text { great part of the interior. } \\
\text { Copper, iron, \&c. }\end{array}$ & \\
\hline Granite ........... & ........... & $\begin{array}{l}\text { Granite of Table-mountain ; } \\
\text { Cape, Paarl, Malmesbury, and } \\
\text { George Districts, Namaqua- } \\
\text { land, \&c. (Minerals-schorl, } \\
\text { garnet, kyanite, fluor-spar,\&c.) }\end{array}$ & \\
\hline Greenstone ....... & .......... & $\begin{array}{l}\text { Greenstone, syenitic greenstone, } \\
\text { basaltic greenstone, amygda- } \\
\text { loid, \&c., occurring chiefly in } \\
\text { beds and dykes in the 'Middle' } \\
\text { and 'UpperCoal-measures'and } \\
\text { in the gneiss. Minerals - calc- } \\
\text { spar, sulphate of barytes (in } \\
\text { one place only), asbestos, epi- } \\
\text { dote, prehnite, agate, chal- } \\
\text { cedony, \&c. The crystalline } \\
\text { felspar-trap, associated with } \\
\text { the copper of Namaqualand, } \\
\text { is more of a greenstone than } \\
\text { granitic in character. A pecu- } \\
\text { liar felspar-trap-conglomerate } \\
\text { occurs in the Roggeveld Spitz. }\end{array}$ & \\
\hline
\end{tabular}




\title{
EXPLANATION OF PLATES V.-IX.
}

\author{
Illustrative of Fossils from South Africa.
}

\section{Plate V.}

Fig. 1. Pecopteris Rubidgei: a, portion of a frond, natural size; $b$, pinnule magnified.

2. Pecopteris Atherstonci: $a$, portion of a frond, natural size; $b$, pinnule, magnified.

3. Palceozamia Rubidgei: a, portion of a frond, natural size; $b$, leaflet, magnified.

4. Palcozania Morrisii: portion of a frond, natural size.

5. Palceozamia Africana: leaflet, natural size.

6. Phyllotheca, sp.: portion of stem, natural size.

7. Palcozamia (Otozamites) recta: $a$, portion of a frond; $b$, leaflet magnified.

8. Rubidgea Mackayi: a frond, natural size.

\section{Plate VI.}

Fig. 1. Pecopteris Africana: $a$, portion of a frond, natural size; $b$, pinnule magnified.

2. Glossopteris Sutherlandi: $a$, portion of a frond, natural size; $b$, magnified.

3. Sphenopteris antipodum: portion of a frond, natural size.

4. Cyclopteris Jenkinsiana: portion of a frond, natural size.

5. Glossopteris Browniana: a, upper portion of a frond, natural size; $b$, lower portion, natural size.

6. Dictyopteris? simplex: portion of a frond, natural size.

7. Glossopteris Browniana: $a$, portion of a broad frond, natural size; $b$, portion of the same, magnified.

\section{Plate VII.}

Fig. 1. Patella caperata, natural size: $a$, side view; $b$, view from above.

2. Belemnites Africanus, natural size: $a$, ventral aspect; $b$, transverse aspect of the alveolar region.

3. Ammonites subanceps, natural size: $a$, view showing the back; $b$, side view.

4. Hamites Africanus, natural size: a, lateral view, with a portion of the shell to exhibit the foliations; $b$, lateral view of a portion of a shell of large diameter; $c$, ventral view of a small specimen; $d$, ventral view of specimen $b$.

5. Lima neglecta: $a$, shell, twice the natural size; $b$, a portion of the shell, magnified.

6. Trigonia Goldfussi, enlarged threo times.

7. Alaria coronata, natural size.

8. Cardita nuculoides: $a$, viewed from above: $b$, from thefront; $c$, side view : all enlarged two times; $d$, portion of the shell, much magnified.

9. Trigonia ventricosa: young shell, twice the natural size.

10. Cypricardia Niveniana, natural size.

11. Pecten Rubidgeanus, twice the natural size.

\section{Plate VIII.}

Fig. 1. Berenicea antipodum: $a$, natural size; $b$, a portion highly magnified.

2. Cyprina Borcherdsi, natural size.

3. Ostrea (Exogyra) Jonesii: a, exterior of an attached valve; $b$, interior of another specimen; $c$, exterior of the same; all slightly enlarged.

4. Mytilus Jonesii: $a$, lateral view; $b$, side view : natural size.

5. Astarte Longlandsiana : $a$, side view; $b$, dorsal aspect of the closed valves.

6. Turritella Rubidgeana: $a$, natural size; $b$, enlarged three times.

7. Placunopsis imbricata, natural size.

8. Corbula Rockiana, slightly enlarged. 
Quart, Inurn. Geol Soc. Vol, XXIII. PI.V.

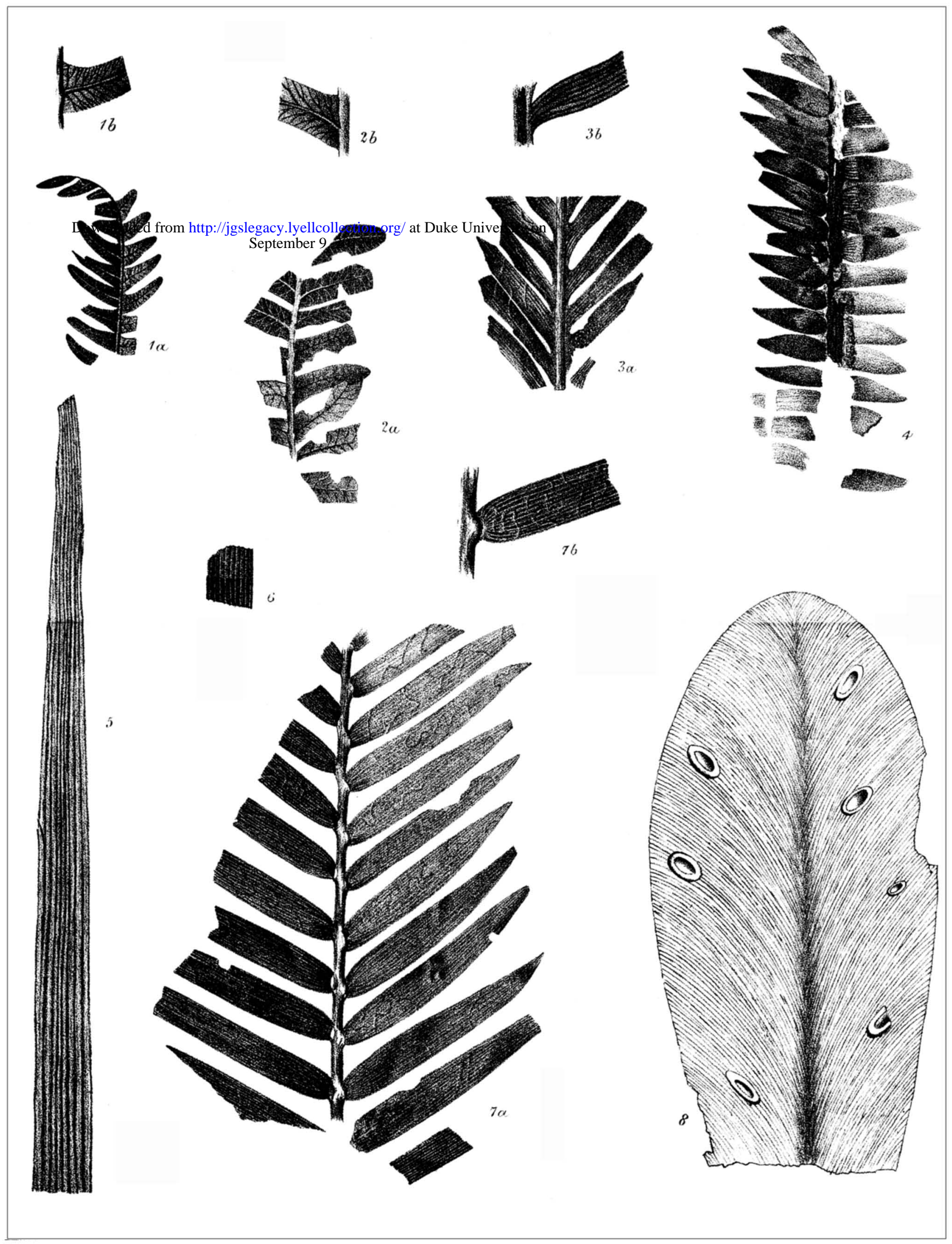




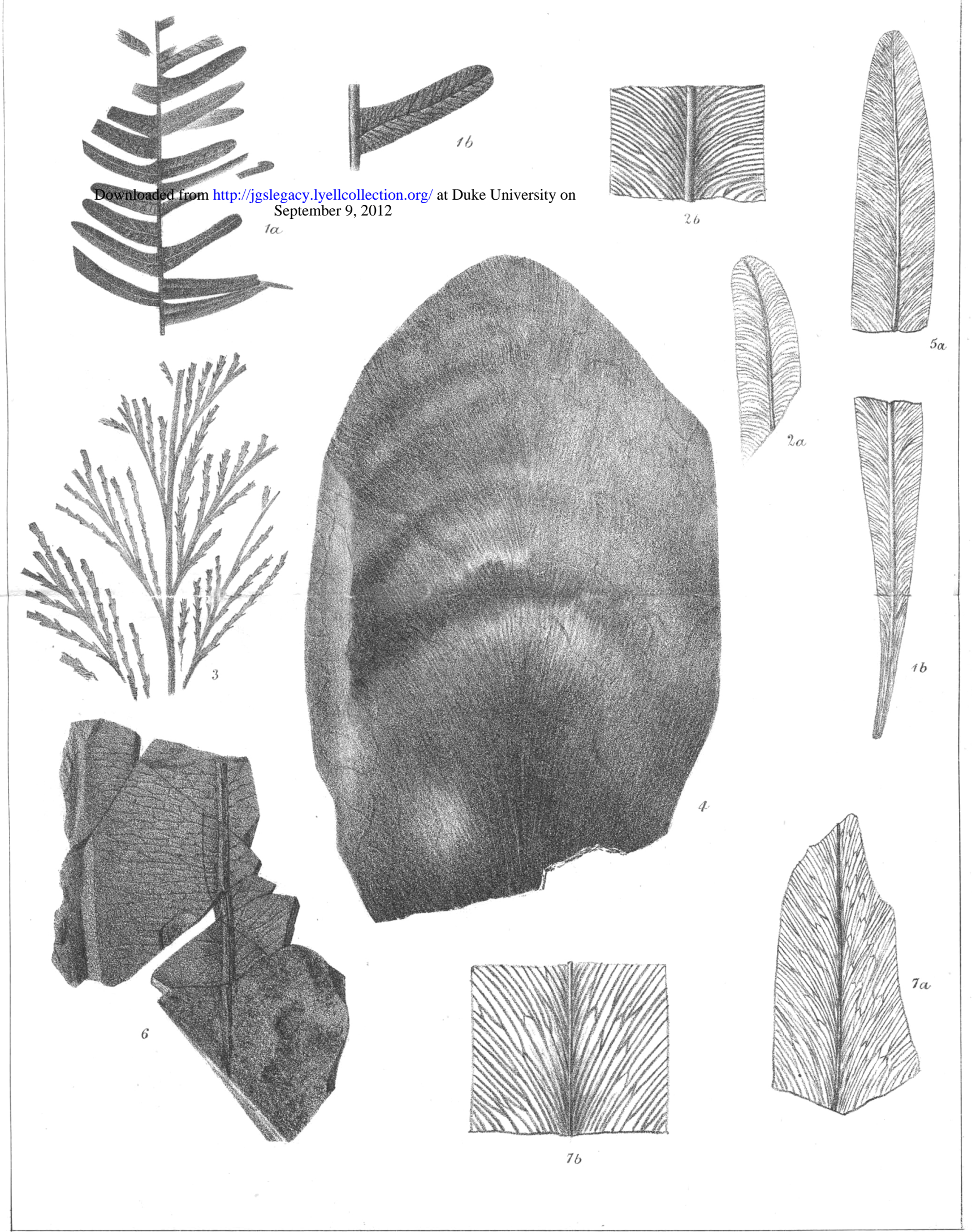


OUdaxt..Journ.Ceol.Soe Vol.XXIIL.PI.VII.

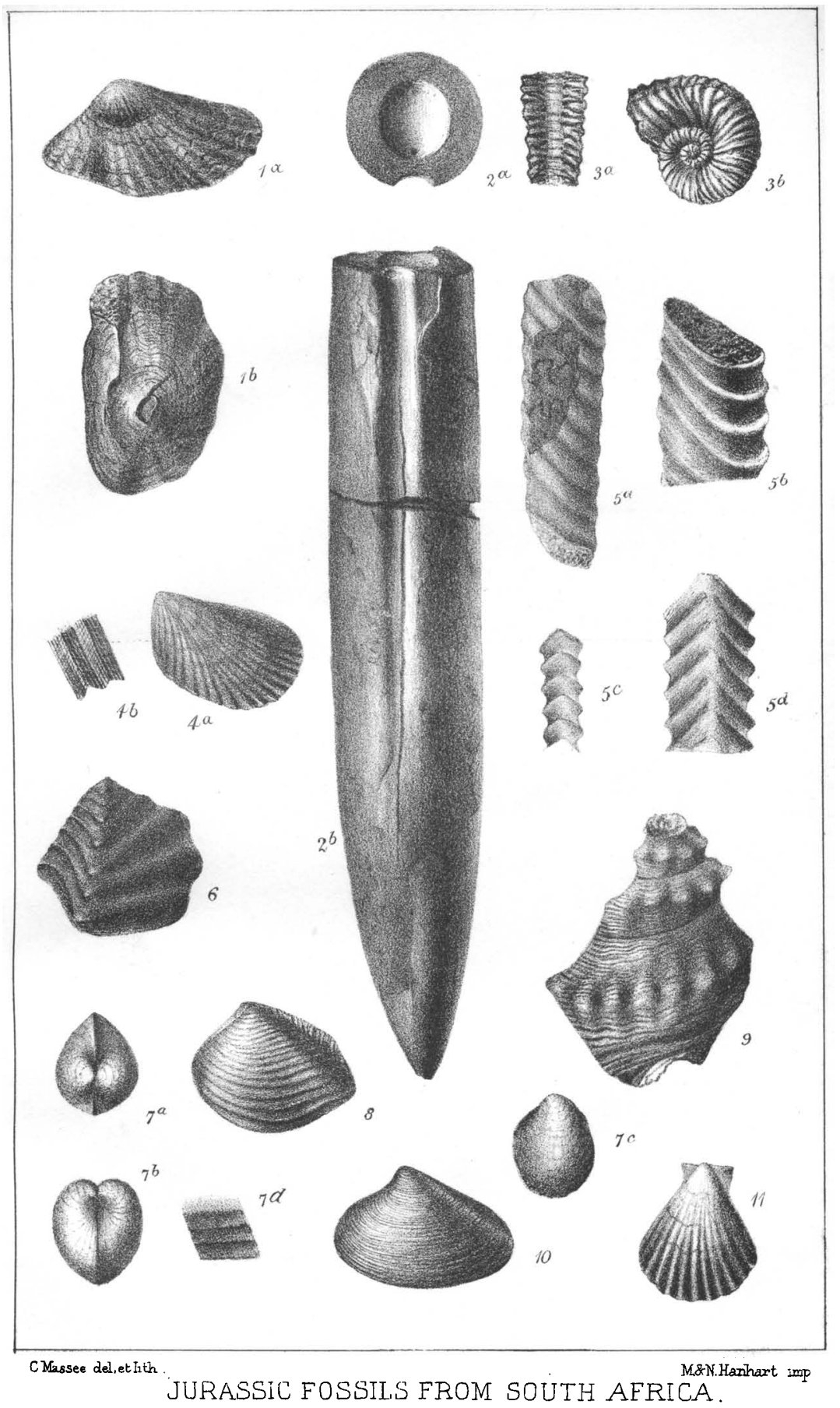


Downloaded from http://jgslegacy.lyellcollection.org/ at Duke University on September 9, 2012

Cuart Joum Ceol. Soc.VoI.XXIII. PI.VIII,

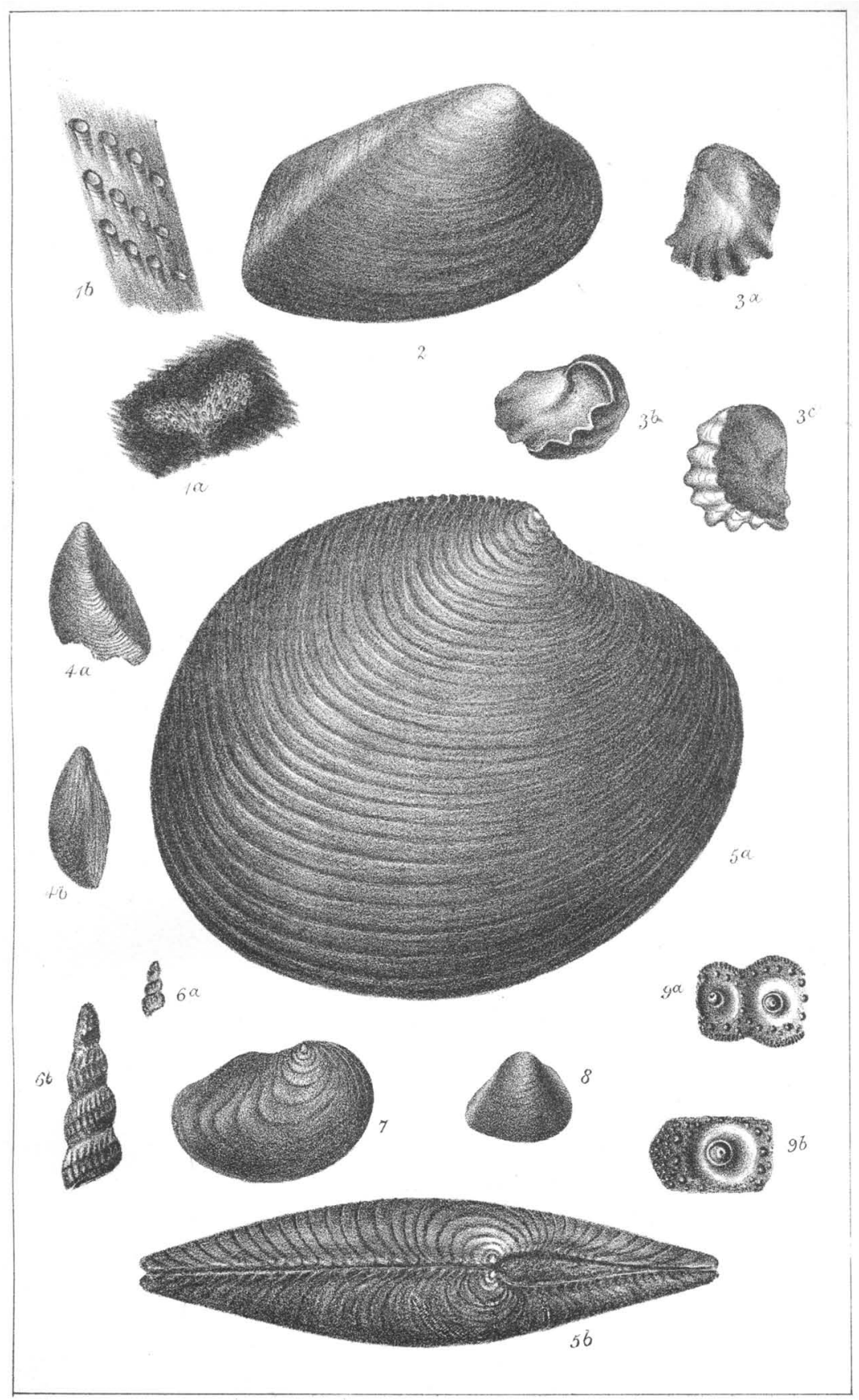

GMassee del.et]ithr. M\&N Harhart ino JURASSIC FOSSILS FROM SOUTH AFRICA 
Downloaded from http://jgslegacy.lyellcollection.org/ at Duke University on September 9, 2012

Quart.Journ.Geol.Soc.Vol XXIII.PI.IX.

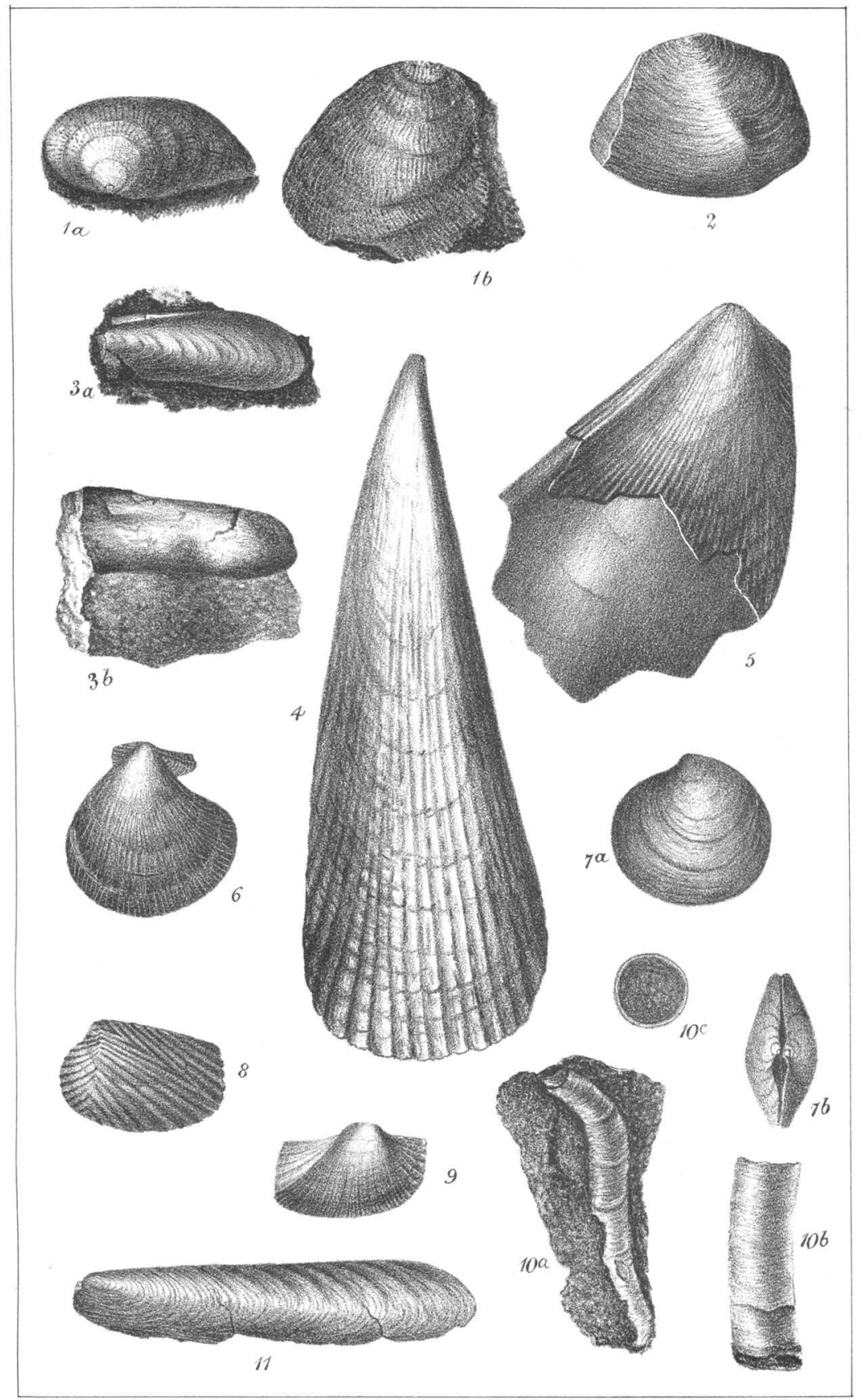

GMasse del.et lith 


\section{Plate IX.}

Fig. 1. Placunopsis subjurensis: $a$, umbonal aspect; $b$, lateral aspect: natural size.

2. Placunopsis undulata, natural size.

3. Mytilus (Lithodomus) Stowianus: a, posterior moiety of the shell; $b$, anterior of another specimen: both of the natural size.

4. Pinna Sharpei, natural size.

5. Lima obliquissima, natural size.

6. Pecten projectus, natural size.

7. Astarte Pinchiniana: $a$, lateral aspect; $b$, view of the dorsal region; natural size.

8. Crassatella complicata, natural size.

9. Arca Jonesii, natural size.

10. Vermilia Pinchiniana: $a$, attached portion ; $b$, free portion; $c$, transverse section of the same: natural sizes.

11. Mytilus Rubidgei, natural size.

2. Further Remaris upon the Retation of the Chichesford Beds to the Fluviomarine Crag. By the Rev. O. Fisher, M.A., F.G.S.

\section{(Abstract.)}

THe author dissents from the interpretation of two pit-sections, one on Aldringham Common, the other near Henham Park Farm, given by Mr. Searles Wood in his paper "On the Structure of the Red Crag." Mr. Fisher admits that the former is at a higher level than the Thorpe Crag-pit, and the latter than the Wangford Crag; but he denies that the loam on Aldringham Common is Chillesford clay, and is doubtful whether even that at Henham Park Farm belongs to that deposit. Granting, however, that the loam in the latter case is really Chillesford clay, the author states that it is probably carried under the Wangford Crag by a northern dip. Thus he considers that neither of these sections contains indisputable evidence of the superposition of the Chillesford clay to the Fluviomarine Crag. He also expresses a doubt of the crag at Bulchamp being a continuation of the Wangford bed, and states that it much more resembles the Mya-bed as seen at Yarn Hill.

P.S. A subsequent examination of the neighbourhood of Norwich in April 1867, led the author to admit the identity of the Mya-bed with the Upper Crag of Mr. Taylor, as seen at Toft Monks and Bramerton; and consequently to abandon such of his published opinions as are inconsistent with that conclusion.-O. F.

\section{February 20, 1867.}

The Right Hon. the Earl de Grey and Ripon, 1 Carlton Gardens, S.W. ; Frank Clarkson, Esq., 27 Oakley-street, S.W.; James Diggens, Esq., Secretary to the Royal Albert Idiot Asylum; and Joseph Lucas, Esq., of the Geological Survey of Great Britain, Museum, Jermyn-street, S.W., were elected Fellows :-

The following communications were read:- 